\title{
Petrogenesis and Tectonic Setting of Early Cretaceous Intrusive Rocks in the Northern Ulanhot Area, Central and Southern Great Xing'an Range, NE China
}

\author{
Baoqiang Tai ${ }^{1,+}$, Wentian Mi ${ }^{2,3, *,+}+\mathbb{D}$, Genhou Wang ${ }^{1}$, Yingjie $\mathrm{Li}^{4}$ and Xu Kong ${ }^{5}(\mathbb{D}$ \\ 1 School of Earth Science and Resources, China University of Geosciences, Beijing 100083, China; \\ tbq@cugb.edu.cn (B.T.); wgh@cugb.edu.cn (G.W.) \\ 2 State Key Laboratory of Oil and Gas Reservoir Geology and Exploitation, Chengdu University of Technology, \\ Chengdu 610059, China \\ School of Mines, Inner Mongolia University of Technology, Hohhot 010051, China \\ 4 School of the Earth Sciences, Hebei GEO University, Shijiazhuang 050030, China; liyingjie820@126.com \\ 5 Department of Geology, Northwest University, Xi'an 710069, China; konx163@163.com \\ * Correspondence: miwentian1982@imut.edu.cn \\ + These authors contributed equally to the work.
}

check for

updates

Citation: Tai, B.; Mi, W.; Wang, G.; Li, Y.; Kong, X. Petrogenesis and Tectonic Setting of Early Cretaceous Intrusive Rocks in the Northern Ulanhot Area, Central and Southern Great Xing'an Range, NE China. Minerals 2021, 11, 1414. https://doi.org/10.3390/ $\min 11121414$

Academic Editors: Sung Won Kim and Seong-Jun Cho

Received: 12 October 2021

Accepted: 10 December 2021

Published: 14 December 2021

Publisher's Note: MDPI stays neutral with regard to jurisdictional claims in published maps and institutional affiliations.

Copyright: (c) 2021 by the authors. Licensee MDPI, Basel, Switzerland. This article is an open access article distributed under the terms and conditions of the Creative Commons Attribution (CC BY) license (https:/ / creativecommons.org/licenses/by/ $4.0 /)$.

\begin{abstract}
Abundant Early Cretaceous magmatism is conserved in the central and southern Great Xing'an Range (GXR) and has significant geodynamic implications for the study of the Late Mesozoic tectonic framework of northeast China. In this study, we provide new high-precision $\mathrm{U}-\mathrm{Pb}$ zircon geochronology, whole-rock geochemistry, and zircon Hf isotopic data for representative intrusive rocks from the northern part of the Ulanhot area to illustrate the petrogenesis types and magma source of these rocks and evaluate the tectonic setting of the central-southern GXR. Laser ablation inductively coupled plasma-mass spectrometry (LA-ICP-MS) zircon U-Pb dating showed that magmatism in the Ulanhot area (monzonite porphyry: $128.07 \pm 0.62 \mathrm{Ma}$, quartz monzonite porphyry: $127.47 \pm 0.36$, quartz porphyry: $124.85 \pm 0.34$, and granite porphyry: $124.15 \pm 0.31 \mathrm{Ma}$ ) occurred during the Early Cretaceous. Geochemically, monzonite porphyry belongs to the metaluminous and alkaline series rocks and is characterized by high $\mathrm{Al}_{2} \mathrm{O}_{3}$ (average $17.74 \mathrm{wt} . \%$ ) and $\mathrm{TiO}_{2}$ (average $0.88 \mathrm{wt} . \%$ ) and low $\mathrm{Ni}$ (average $4.63 \mathrm{ppm}$ ), $\mathrm{Cr}$ (average $6.69 \mathrm{ppm}$ ), $\mathrm{Mg}^{\#}$ (average 31.11), Y (average $15.16 \mathrm{ppm}$ ), and $\mathrm{Yb}$ (average $1.62 \mathrm{ppm}$ ) content with enrichment in $\mathrm{Ba}, \mathrm{K}, \mathrm{Pb}, \mathrm{Sr}, \mathrm{Zr}$, and $\mathrm{Hf}$ and depletion in $\mathrm{Ti}, \mathrm{Nb}$, and Ta. The granitic rocks (e.g., quartz monzonite porphyry, quartz porphyry, and granite porphyry) pertain to the category of high-K calc-alkaline rocks and are characterized by high $\mathrm{SiO}_{2}$ content (>66 wt.\%) and low $\mathrm{MgO}$ (average 0.69 wt.\%), $\mathrm{Mg}^{\#}$ (average 31.49 ppm), Ni (average 2.78 ppm), and $\mathrm{Cr}$ (average $8.10 \mathrm{ppm}$ ) content, showing an affinity to I-type granite accompanied by $\mathrm{Nb}, \mathrm{Ta}, \mathrm{P}$, and Ti depletion and negative Eu anomalies ( $\delta \mathrm{Eu}=0.57-0.96$; average 0.82$)$. The Hf isotopic data suggest that these rocks were the product of the partial melting of juvenile crustal rocks. Notably, fractionation crystallization plays a crucial role in the process of magma emplacement. Combining our study with published ones, we proposed that the Early Cretaceous intrusive rocks in the Ulanhot area were formed in an extensional tectonic background and compactly related to the subduction of the Paleo-Pacific Ocean plate.
\end{abstract}

Keywords: LA-ICP-MS zircon U-Pb dating; Hf isotopic; early cretaceous; Paleo-Pacific Ocean plate; central and southern Great Xing'an Range

\section{Introduction}

Northeast (NE) China, which is well-known for its extensive distribution of Late Mesozoic igneous rocks [1-8], is situated in the eastern segment of the Central Asian Orogenic Belt and bounded by the northern part of the North China Craton, the southern part of the Siberia Craton and the western Pacific rim (Figure 1a) [9-20]. During the Late Mesozoic, 
this region experienced multi-stage structural superposition and tectonic reformation of the Paleo-Pacific Ocean (PPO) and Mongol-Okhotsk Ocean tectonic domains, recording multiple tectonic-thermal events of different scales by widespread intrusive rocks [13,21-27]. It has been a hot area for the interpretation of mantle-crust interactions and crustal evolution over the past two decades and an important metallogenic belt (Figure 1b) [28-35]. In particular, as a key component of NE China, the Great Xing'an Range (GXR) exhibits voluminous Early Cretaceous granitoids (Figure 1c) [2,36-39], indicating that tectonic-magmatic activity peaked during the Early Cretaceous [1,7,40-44]. Numerous geochronology and geochemistry facts show that the granitic rocks of the GXR were formed in an extensional tectonic environment during the Early Cretaceous $[2,29,30,45]$. However, there is still some debate regarding the petrogenesis and geodynamic background of these rocks, including the following explanations: (1) the upwelling magmas associated with the mantle plume [9,46]; (2) a post-collision gravitational collapse of the Mongol-Okhotsk Ocean plate [47-52]; (3) lithospheric delamination induced by the contribution of westward subduction of the Paleo-Pacific slab [53-56]; and (4) retreat of the PPO plate and the successive upwelling of the varying degrees of asthenospheric mantle [35,57-59]. The above disputes indicate that the GXR has frequent tectonomagmatic activity and complex tectonic settings [56,60-62]. Either way, clarifying the petrogenesis, magma source of the intrusive rocks, and intensive crust-mantle interaction of the GXR are vital steps in explaining the tectonic evolution history of the PPO plate and the Mongol-Okhotsk Ocean plate and mastering the GXR tectonic frameworks during the Early Cretaceous.

Regional geological data show that previous geochronological, geochemical, and isotopic studies mainly focused on the northern and southern parts of the GXR $[32,34,57,58,63]$, but few studies have focused on the central-southern segment $[1,16,17,64]$. The Ulanhot area, characterized by extensive intrusions (Figure 2), is affiliated with the central and southern part of GXR and located at the junction of the Xing'an block and the Songnen block, which is a favorable place to study the Early Cretaceous tectonic setting of GXR. In this study, we provided new high-precision $\mathrm{U}-\mathrm{Pb}$ zircon age testing, whole-rock geochemical measurements, and zircon Lu-Hf isotopic analysis for representative intrusive rocks from the northern part of the Ulanhot region, with the purpose of illustrating the formation time, petrogenesis types, and magmatic origin of these rocks, further discussing their geodynamic implications and evaluating the tectonic background of this place, thus restricting the evolution of tectonic magmatic history in the GXR during the Early Cretaceous. 

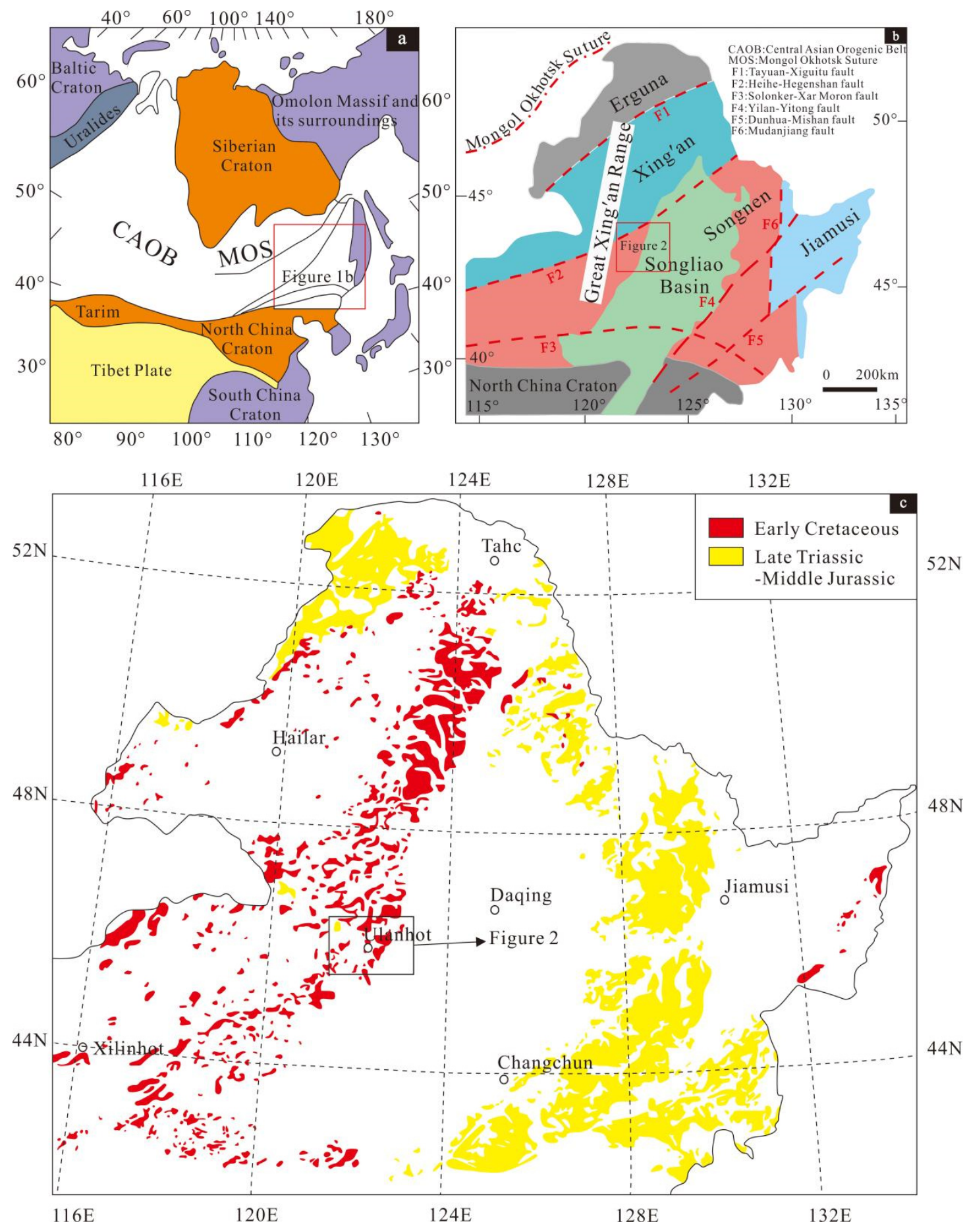

Figure 1. (a) Tectonic sketch map of Northeast Asia and the position of Figure 1b (modified after Wu et al. [2] and Zhang et al. [63]). (b) Simplified tectonic map of NE China (modified after Wu et al. [2] and Wang et al. [65]) and the position of Figure 2. (c) Distribution of the Late Mesozoic granitoids in NE China (modified after Wu et al. [2], Li et al. [38], and Pang et al. [39]).

\section{Geological Background and Sample Descriptions}

2.1. Geological Background

From the point of view of plate tectonics, NE China belongs to the eastern section of the Central Asian Orogenic Belt (Figure 1a) $[4-6,8,9,18,24,39,63]$ and is confined between the Solonker-Xar Moron suture zone on the northern margin of the North China Craton and the Mongol Okhotsk suture zone on the southern margin of the Siberia Craton, with the western Pacific coastal zone to the east (Figure 1b) $[7,10-13,16,17,19,20,32,53,65]$. The main body of 
NE China is actually composed of Erguna, Xing'an, Songnen, and Jiamusi block systems, interspersed with a series of microcontinental masses, which correspond to subduction and closure of the events in the Paleo-Asian Ocean during the Palaeozoic to Early Mesozoic eras $[25,26,29,35,66]$. In terms of the regional structure, the Tayuan-Xiguitu fault zone, Heihe-Hegenshan fault zone, and Yilan-Yitong fault zone indicate the boundaries of these blocks from northwest to southeast $[6,18,40,67,68]$, and the Solonker-Xar Moron suture zone marks the final collage demarcation line between the North China Craton and the blocks of NE China during the Late Permian-Middle Triassic period [17,35,69,70]. Since the Mesozoic era, NE China has experienced multi-stage structural superposition and tectonic reformation of the PPO and Mongol-Okhotsk Ocean tectonic domains, forming extensive Mesozoic volcanic and granitic rocks (Figure 1c) $[16,17,26,43,53,71]$ and constraining the patterns of crustal growth and crust-mantle interaction in this region [7,24,25,32,63,72]. With the development of research, the subduction of the Mongol-Okhotsk Ocean plate dated from the early Mesozoic [45,73,74], and this paleo-ocean closed in a scissor-like mode from west to east and eventually disappeared in the Amur region in the Late Jurassic [55,74]. Additionally, the age of magmatic rocks in NE China tended to decrease from west to east during the Early Cretaceous [57], implying that subduction and closing of the MongolOkhotsk Ocean may not have predominated the magmatic evolution of NE China during this period $[4,35]$. Notably, the subduction of the PPO plate was a complex multi-stage and multi-directional evolution process $[1,8,61,72,75]$, and the initial subduction time of the PPO plate to the Eurasia probably emerged earlier than the Early Jurassic $[24,35,45,57]$. Since the Late Mesozoic period, especially after the closure of the Mongolian-Okhotsk Oceanic during the Late Jurassic $[45,55]$, the intense subduction of the PPO plate has restrained the tectonomagmatic evolution and crust-mantle interaction of NE China $[8,25,35,76]$.

The NNE-trending GXR lies in the western segment of NE China and maintains a record of abundant magmatism since the Phanerozoic (Figure 1c) $[23,33,39,55,71]$. The GXR comprises various structure-rock assemblages connected with Paleozoic island-arc evolution theories, including without the limitation of shallow-sea limestones, metamorphic and volcanic sedimentary rocks, fine-grained clastic rocks, and widespread igneous intrusions [2,39], and is almost overlaid by voluminous Mesozoic magmatite [3,38,39]. The Mesozoic magmatite primarily involves the extensive allocation of the Late Jurassic-Early Cretaceous volcanics [16,17] and the Late Triassic-Middle Jurassic and Early Cretaceous granitoids (Figure 1c) $[38,68,76]$. The volcanic types of the GXR refer to the Tamulangou, Manitu, Manketouebo, Baiyingaolao, and Meiletu formations [23,64,77,78], mainly containing basalt, andesite, dacite, rhyolite, and volcanic breccia [79]. The Late Triassic-Middle Jurassic granites are mainly distributed on the northern sides of the GXR, whereas the Early Cretaceous granites are distributed throughout the GXR (Figure 1c) [39].

The Ulanhot area is affiliated with the central and southern part of the GXR [16] and located at the junction of Xing' an and Songliao blocks (Figure 1b). As the western boundary fault of the Songliao Basin [80], the Nenjiang-Balihan fault zone runs through the southeast of the study area, primarily presenting as the NE trending sinistral strike-slip ductile shear deformation, and its strike-slip time was during the Early Cretaceous [78,81]. The main exposed strata in this area are Permian and Jurassic, among which Permian strata are composed of Early Permian clastic, andesite, and dacite rocks; Middle Permian carbonate or clastic rocks; and Late Permian turbidite deposits, whereas Jurassic strata consist of dacite, rhyolite, and rhyolite tuff $[16,77]$. The intrusive rocks, including Permian biotite granites, granite gneiss, Early Cretaceous monzonite, quartz monzonite, and granite porphyry (Figure 2) $[23,78,82,83]$, are in unconformity contact with the volcanic strata, suggesting that tectonomagmatic activity in the study area is frequent, and a more detailed understanding of its formation ages and diagenetic processes contribute to explaining the tectonic evolution patterns of GXR in NE China during the Mesozoic era. 


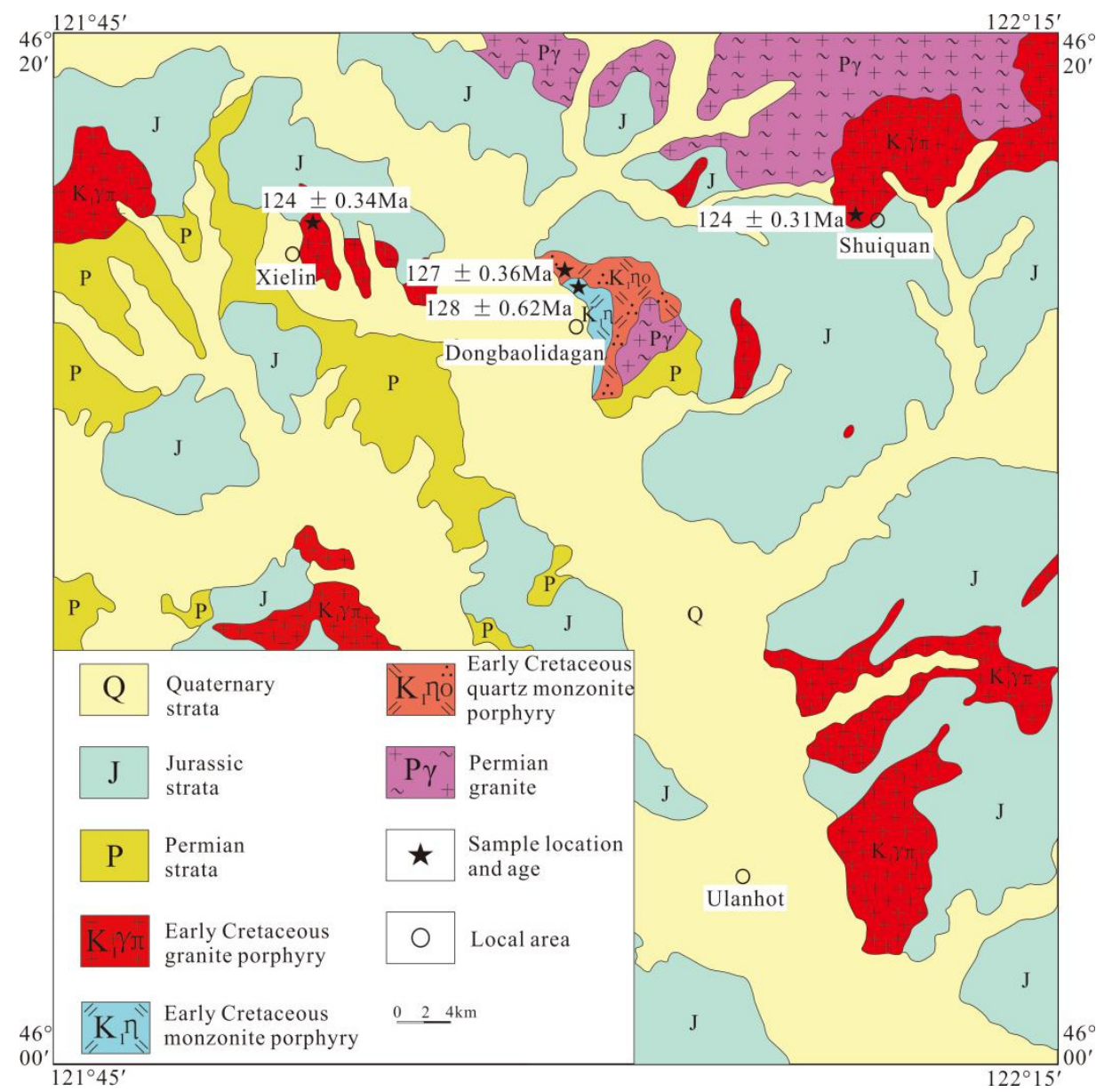

Figure 2. Simplified 1:200,000 regional geological survey map and sample locations of the Ulanhot area.

\subsection{Sample Descriptions}

Typical intrusive rocks were collected approximately $21 \mathrm{~km}$ north of the Ulanhot area. A total of 14 samples from four rock masses (Figure 2), which have not been previously reported, were selected for geochronology, geochemistry, and Hf isotope analysis.

The hand specimen of the quartz monzonite porphyry in the Dongbaolidagan area was light red (Figure 3a), with a lumpy texture and porphyritic structure, and the matrix exhibited an aphanocrystalline or microcrystalline texture.

The porphyritic crystals were mainly made up of K-feldspar $(1.0-3.0 \mathrm{~mm} ; 15 \%)$, plagioclase $(0.5-2.5 \mathrm{~mm} ; 5 \%)$, and a small amount of quartz $(0.5-1.0 \mathrm{~mm} ; 2 \%)$, with the felsic aphanocrystalline matrix (Figure 3b).

The monzonite porphyry samples from the Dongbaolidagan area were celandine green (Figure 3c), clearly showing a massive structure and porphyritic texture with an aphanocrystalline matrix structure. Porphyritic crystals were made up of plagioclase $(1.0-2.0 \mathrm{~mm} ; 10 \%)$ and K-feldspar $(1.0-5.0 \mathrm{~mm} ; 8 \%)$, and the aphanocrystalline matrix was mainly feldspar minerals (Figure $3 \mathrm{~d}$ ).

The sample characteristics of the quartz porphyry from the Xielin area were gray-white (Figure 3e), revealing a broadly massive structure and a porphyritic texture with a ground mass of aphanitic matrix structure. The porphyritic crystals were primarily composed of round quartz $(0.5-2.5 \mathrm{~mm} ; 20 \%)$, with a visible erosion structure, and the matrix was mostly aphanocrystalline or microcrystalline quartz and feldspar (Figure 3f). 

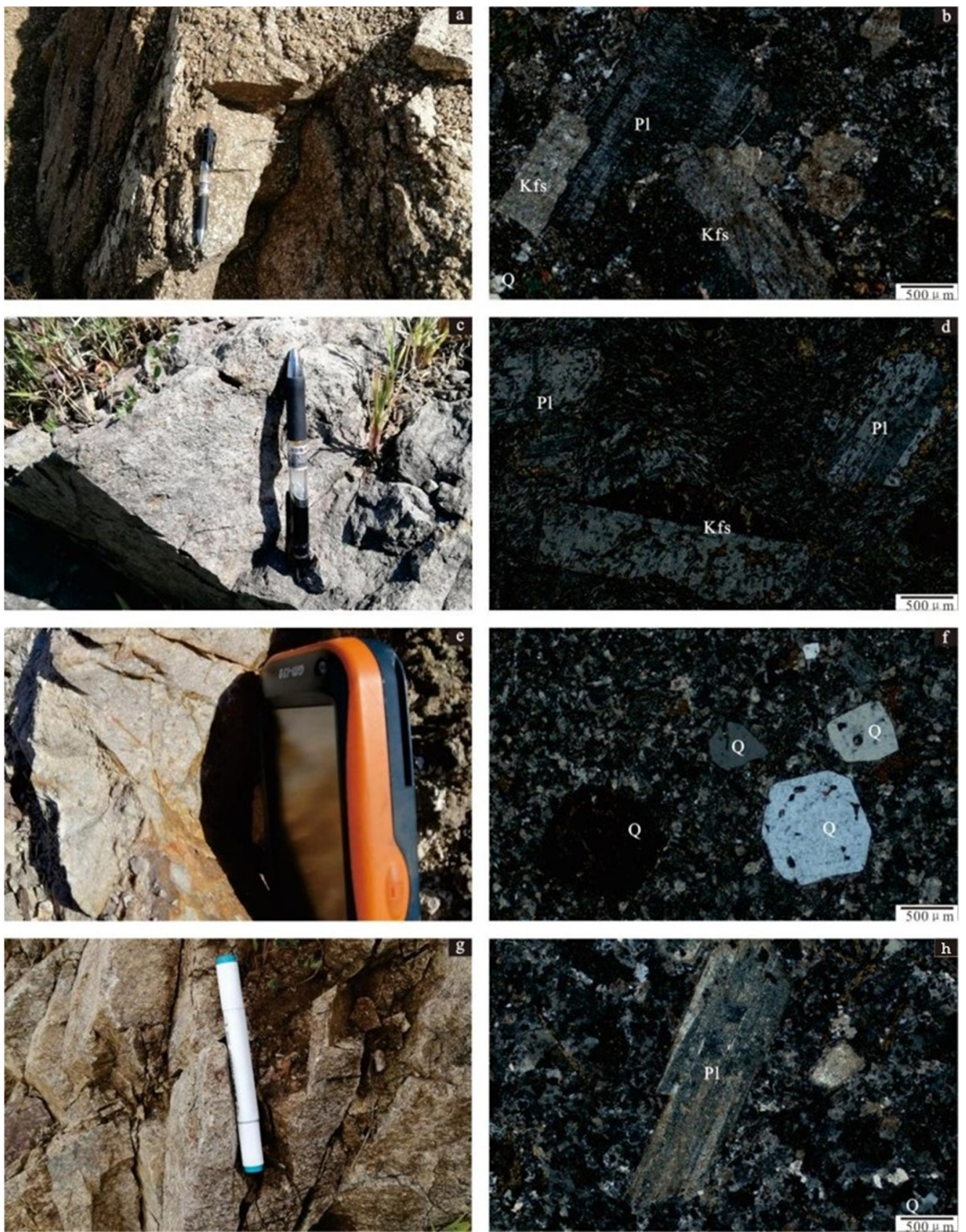

Figure 3. Field photographs and typical microphotographs of the intrusive rocks in the northern part of the Ulanhot area: (a,b) quartz monzonite porphyry (Sample DBb04); (c,d) monzonite porphyry (Sample DBb08); (e,f) quartz porphyry (Sample XLb04); (g,h) granite porphyry (Sample SQb13); Q: quartz; Pl: plagioclase; Kfs: K-feldspar.

The granite porphyry samples of Shuiquan were gray-yellow (Figure 3g) and also revealed a massive structure and a porphyritic texture with an aphanocrystalline or microcrystalline texture. The porphyritic crystals were mainly composed of plagioclase (0.5-5.0 $\mathrm{mm} ; 10 \%)$ and a small amount of quartz $(0.5-1.0 \mathrm{~mm} ; 2 \%)$, and the components of the matrix were mainly composed of quartz and feldspar minerals (Figure $3 \mathrm{~h}$ ).

\section{Analytical Methods}

\subsection{Zircon $\mathrm{U}-\mathrm{Pb}$ Dating and $\mathrm{Hf}$ Isotope Analysis}

In this study, the samples of DBT01, DBT02, XLT01, and SQT01 intrusive rocks from the northern part of the Ulanhot area were selected for zircon $\mathrm{U}-\mathrm{Pb}$ dating and $\mathrm{Hf}$ isotopic 
analysis of in situ zircon. First, the zircon grains were routinely crushed in the Mineral Separation Laboratory of the Beijing GaoAnalysis Technology Co. Ltd., Beijing, China and then separated by the technical methods of heavy liquid and magnetic separation. Second, these particles were observed under a binocular microscope, handpicked, installed onto gummed tape, encapsulated in an epoxy resin, and polished to a thickness of approximately $1 / 3$ to $1 / 2$ for further analysis. It is worth mentioning that before we performed the $\mathrm{U}-\mathrm{Pb}$ isotope analysis, the internal construction of zircon grains was investigated using transmission electron microscopy and then by a JEOLJSM-6510 scanning electron microscope with a MiniCL detector at the Key Laboratory of Mineral Resources in Western China (Lanzhou, Gansu) to obtain clear images of backscattered electrons and cathode luminescence (CL). Subsequently, the $\mathrm{U}-\mathrm{Pb}$ isotope analysis target area was selected by using the CL images obtained previously to carry out the dating studies, which were performed on an inductively coupled plasma-mass spectrometry (ICP-MS) spectrometer (Agilent Ltd.) with a 193-nm Analyte excimer laser-ablation system (Photon Machines Inc.) at the Key Laboratory of Mineral Resources in Western China (Lanzhou, Gansu). In this experiment, the laser ablation spot magnitude was approximately $30 \mu \mathrm{m}$ with a repeat frequency of $8 \mathrm{~Hz}$, and the carrier gas consisted of high-purity He gas. Harvard zircon 91,500 and silicate glass NIST 610 were regarded as the external standards to normalize isotope fractionation in the analysis process and calculate the $\mathrm{U}, \mathrm{Th}$, and $\mathrm{Pb}$ concentrations of zircons. Meanwhile, the $208 \mathrm{~Pb}$ method was always accustomed to $\mathrm{Pb}$ correction to guarantee measurement validity and accuracy [84]. All testing outcomes were handled by Glitter software, version 4.0, and the diagrams of zircon $\mathrm{U}-\mathrm{Pb}$ age concordia and weighted mean age were pictured using Isoplot software [85]. In addition, the error of age data and consistency graphs were reported at $1 \sigma$, and the confidence level of the weighted mean age uncertainties was reported to be $95 \%$.

In situ zircon Hf isotopic analyses were performed at or near the age point of the chosen zircon grains and conducted using a Thermo Fisher Neptune MC-ICP-MS system and linked to a Resolution SE193 nm laser ablation system at the Isotope Geology Laboratory of the Beijing GaoAnalysis Technology Co. Ltd., Beijing, China. The laser ablation spot magnitude was $38 \mu \mathrm{m}$ with a repeat frequency of $10 \mathrm{~Hz}$, and the single-spot ablation mode was utilized for all zircon analyses. More detailed technical theories and methods have been proposed by $\mathrm{Hu}$ et al. [86]. Furthermore, zircon standard 91,500 still served as alignment, inducing a $176 \mathrm{Hf} / 177 \mathrm{Hf}$ percentage of weighted mean at $0.282480 \pm 0.000016$ $(2 \sigma)$ and in harmony with the preferred values within the scope of error [87]. The zircon Hf isotope data were processed using the Geokit software package [88,89], and the isotopic parameters used to calculate $\varepsilon \mathrm{Hf}(\mathrm{t})$ and $\mathrm{Hf}$ model ages were mainly as follows: $\lambda^{176}=1.867 \times 10^{-11} \mathrm{a}^{-1}$ [90], (176Lu/177Hf) ${ }_{\mathrm{CHUR}}=0.0332$ [91], $(176 \mathrm{Hf} / 177 \mathrm{Hf})_{\mathrm{CHUR}}=$ 0.282772 [91,92], $(176 \mathrm{Lu} / 177 \mathrm{Hf})_{\mathrm{DM}}=0.0384$ [93], $(176 \mathrm{Hf} / 177 \mathrm{Hf})_{\mathrm{DM}}=0.28325$ [93], and $(176 \mathrm{Lu} / 177 \mathrm{Hf})_{\mathrm{CC}}=0.015[94,95]$.

\subsection{Major and Trace Element Determinations}

Systematically, 14 intrusive rock samples were selected for whole-rock geochemical determination of major and trace elements in the Isotope Laboratory of the Beijing GaoAnalysis Technology Co. Ltd., Beijing, China. First, the altered rock faces were removed, and the fresh rock sample segments were cut and ground through a 200 mesh. The loss on ignition of the samples was subsequently acquired by baking at $1000{ }^{\circ} \mathrm{C}$ in a high-temperature furnace for $1 \mathrm{~h}$. The Shimadzu X-ray fluorescence analysis (XRF; 1800-type) was used for major element analysis of these samples on a fused glass disk, with an analytical precision of more than $5 \%$. The abundance of trace elements and rare earth elements (REEs) was gauged by ICP-MS (Agilent; 7500-type). The main experimental steps included digesting the prepared samples in a high-pressure Teflon bomb with a $\mathrm{HF}+\mathrm{HNO}_{3}$ mixture at $190{ }^{\circ} \mathrm{C}$ for $96 \mathrm{~h}$, evaporating, cooling, diluting, and then sending the samples for ICP-MS detection. For most elements, the analytical indetermination of trace elements was far better than 
$10 \%$. The detailed sample preparation techniques and analytical process are mentioned in Gao et al. [96].

\section{Results}

\subsection{Zircon $\mathrm{U}-\mathrm{Pb}$ Ages}

The LA-ICP-MS zircon U-Pb dating results of the intrusive rock samples (DBT01, DBT02, XLT01 and SQT01), which were selected from the northern part of the Ulanhot area, are presented in Supplementary Table S1.

The DBT01 (N46 $15^{\prime} 24^{\prime \prime}$, E122 $\left.00^{\prime} 26^{\prime \prime}\right)$ sample of quartz monzonite porphyry was collected from a small stock in the Dongbaolidagan area. The chosen zircon grains of DBT01 appear euhedral to semi-euhedral, with prismatic structures and colorless diaphanous characteristics. These zircons have diameters of 50-150 $\mu \mathrm{m}$ and length-width ratios of 0.5:1 to 2:1 and exhibit fine-scale oscillatory growth textures in the CL images. Furthermore, the Th/U ratios of these zircons ranged from $0.44-8.86$ (average 0.63 ), which is significantly higher than the standard value of 0.3 compared to those of the typical magmatic zircons, revealing their magmatic origin [97]. Excluding the low concordance zircons and captured zircons (no. 16, 22, and 23), we implemented 22 analyses on 22 zircons with better consonance from the DBT01 sample, yielding a weighted mean ${ }^{206} \mathrm{~Pb} /{ }^{238} \mathrm{U}$ age of $127.47 \pm 0.36 \mathrm{Ma}$ (MSWD = 5.26, $n=22$; Figure 4a), which we considered to be the crystallization age of quartz monzonite porphyry.
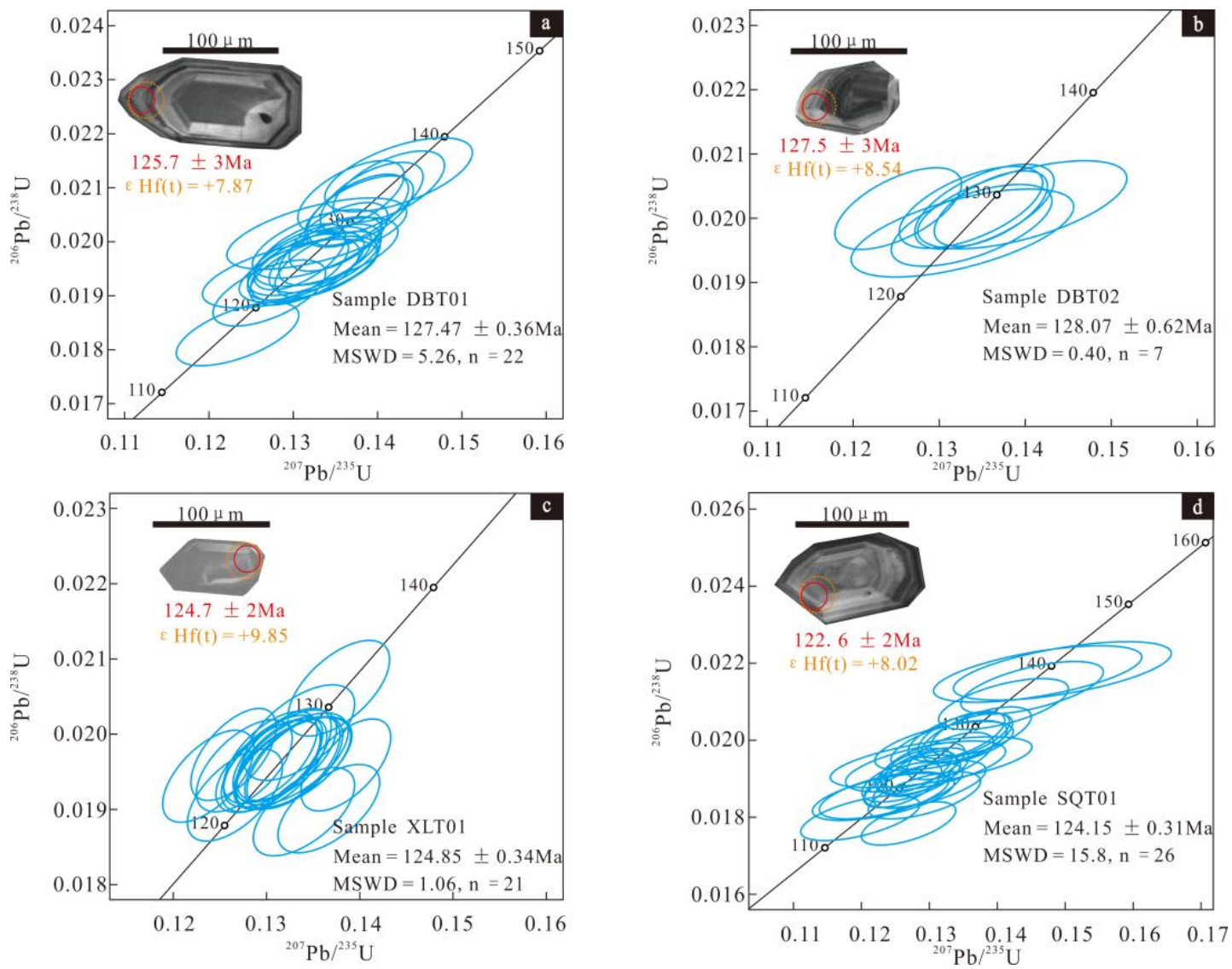

Figure 4. LA-ICP-MS Zircon ${ }^{207} \mathrm{~Pb} /{ }^{235} \mathrm{U}-{ }^{206} \mathrm{~Pb} /{ }^{238} \mathrm{U}$ concordia diagrams of the Early Cretaceous intrusive rocks in the study area: (a) quartz monzonite porphyry; (b) monzonite porphyry; (c) quartz porphyry; (d) granite porphyry. Red circles represent $\mathrm{U}-\mathrm{Pb}$ age analytical spots; orange circles represent $\mathrm{Hf}$ isotope analytical spots.

The DBT02 (N46 $\left.15^{\prime} 21^{\prime \prime}, \mathrm{E} 122^{\circ} 00^{\prime} 29^{\prime \prime}\right)$ sample of the monzonite porphyry, located approximately $100 \mathrm{~m}$ southeast of the DBT01 sample, was selected from a small stock in the Dongbaolidagan area. The zircon grains of DBT02 also appeared clearly euhedral to 
semi-euhedral, with prismatic structures and colorless diaphanous characteristics. The zircons had diameters of 40-100 $\mu \mathrm{m}$ and length-width ratios of 0.5:1 to 1.1:1 and exhibited fine-scale oscillatory growth textures in the CL images. In addition, the Th/U ratios of these zircons ranged from 0.39-0.99 (average 0.63, indicating their magmatic origin [97]). After eliminating the low concordance zircons and captured zircons, we implemented seven analyses on seven zircons (no. 4, 15, 16, 17, 18, 20, and 22) with better consonance from the DBT02 sample, yielding a weighted mean ${ }^{206} \mathrm{~Pb} /{ }^{238} \mathrm{U}$ age of $128.07 \pm 0.62 \mathrm{Ma}$ $(\mathrm{MSWD}=0.40, n=7$; Figure $4 \mathrm{~b}$ ), which was interpreted as the crystallization age of monzonite porphyry.

The XLT01 (N46 $16^{\prime} 33^{\prime \prime}$, E121 $\left.53^{\prime} 10^{\prime \prime}\right)$ sample of quartz porphyry was collected from a small stock in the Xielin area. The zircon grains of XLT01 still appeared euhedral to semi-euhedral, with prismatic structures and colorless diaphanous characteristics. The zircons had diameters of 30-100 $\mu \mathrm{m}$ and length-width ratios of 0.5:1 to $1: 1$ and exhibited fine-scale oscillatory growth textures in the CL images. Additionally, the Th/U ratio of these zircons ranged from 0.35-0.71 (average 0.51), revealing their magmatic origin [97]. After the removal of one low concordance zircon grain (no. 9), we implemented 21 analyses on 21 zircons with better consonance from the XLT01 sample, yielding a weighted mean ${ }^{206} \mathrm{~Pb} /{ }^{238} \mathrm{U}$ age of $124.85 \pm 0.34 \mathrm{Ma}(\mathrm{MSWD}=1.06, n=21$; Figure $4 \mathrm{c})$, which was regarded as the crystallization age of quartz porphyry.

The SQT01 (N46 $\left.17^{\prime} 10^{\prime \prime}, \mathrm{E} 122^{\circ} 10^{\prime} 24^{\prime \prime}\right)$ sample of granite porphyry was collected from a small stock in the Shuiquan area. The zircon grains of SQT01 still appeared visibly euhedral to semi-euhedral, with prismatic structures and colorless diaphanous characteristics. The zircons had diameters of 50-150 $\mu \mathrm{m}$ and length-width ratios of 0.5:1 to 1.5:1 and exhibited fine-scale oscillatory growth textures in the CL images. Additionally, the Th/U ratios of these zircons ranged from 0.52-1.08 (average 0.68), revealing their magmatic origin [97]. After the elimination of one low concordance zircon grain (no. 22), we implemented 26 analyses on 26 zircons with better consonance from the SQT01 sample, yielding a weighted mean $206 \mathrm{~Pb} / 238 \mathrm{U}$ age of $124.15 \pm 0.31 \mathrm{Ma}(\mathrm{MSWD}=15.8, n=26$; Figure $4 \mathrm{~d})$, which we viewed as the crystallization age of granite porphyry.

\subsection{Major and Trace Elements Geochemistry}

To explore the petrogeochemistry of intrusive rocks in the northern part of the Ulanhot area during the Early Cretaceous, a total of 14 fresh samples were selected from four intrusive bodies in the study area; the results of the chemical analyses are summarized in Supplementary Table S2.

The quartz monzonite porphyry samples (DBD01, DBD02, DBD03, and DBD04) from the Dongbaolidagan area were characterized by $\mathrm{SiO}_{2}$ (65.65-66.95 wt.\%; average 66.27 wt.\%), $\mathrm{Al}_{2} \mathrm{O}_{3}$ (15.45-15.95 wt.\%; average 15.62 wt.\%), $\mathrm{Na}_{2} \mathrm{O}$ (4.34-4.57 wt.\%; average 4.45 wt. $\%), \mathrm{K}_{2} \mathrm{O}$ (3.47-3.69 wt.\%; average 3.56 wt.\%), $\mathrm{K}_{2} \mathrm{O}+\mathrm{Na}_{2} \mathrm{O}$ (7.85-8.17 wt.\%; average 8.01 wt. \%), $\mathrm{K}_{2} \mathrm{O} / \mathrm{Na}_{2} \mathrm{O}$ (0.78-0.82), $\mathrm{MgO}$ (1.06-1.17 wt.\%), $\mathrm{CaO}$ (2.39-2.82 wt.\%), $\mathrm{P}_{2} \mathrm{O}_{5}\left(0.134-0.143\right.$ wt.\%), $\mathrm{TiO}_{2}$ (0.45-0.47 wt.\%), $\mathrm{FeO}^{\mathrm{T}}$ (3.39-3.63 wt.\%), and $\mathrm{FeO}^{\mathrm{T}} / \mathrm{MgO}$ (3.04-3.23). According to the total alkali $\mathrm{K}_{2} \mathrm{O}+\mathrm{Na}_{2} \mathrm{O}$ versus $\mathrm{SiO}_{2}$ diagram and the $\mathrm{K}_{2} \mathrm{O}$ versus $\mathrm{SiO}_{2}$ diagram, with a Rittman index $(\sigma)$ of 2.57-2.92, all samples were found to be in the field of quartz-monzonite and high-K calc-alkaline series, respectively (Figure 5a,b).

The A/CNK values (0.95-1.00) suggested that these rocks belonged to the metaluminous rocks series (Figure $5 \mathrm{c}$ ). In the chondrite-normalized REE patterns, the samples had $\sum R E E$ contents of 117.99-126.99 ppm with LREE/HREE values of 9.63-9.76 and $(\mathrm{La} / \mathrm{Yb})_{\mathrm{N}}$ ratios of 10.18-10.40, implying the modest fractionation of the LREE and HREE (Figure 6a).

Further, all the samples showed high Sr (401-574 ppm; average 480 ppm) and Ba (9821077 ppm; average 1038 ppm) content and low Y (14.1-15.9 ppm; average 15.1 ppm) and $\mathrm{Yb}(1.71-1.83 \mathrm{ppm}$; average $1.75 \mathrm{ppm})$ content, with weakly negative $\mathrm{Eu}(\delta \mathrm{Eu}=0.82-0.89$; average 0.86) anomalies (Supplementary Table S2). Moreover, in the primitive mantlenormalized spider diagram (Figure 6b), these samples were characterized by relative enrichment in $\mathrm{Ba}, \mathrm{K}, \mathrm{Pb}$, and $\mathrm{Hf}$ content, and obvious depletion in $\mathrm{Nb}, \mathrm{Ta}, \mathrm{P}$, and Ti content. 

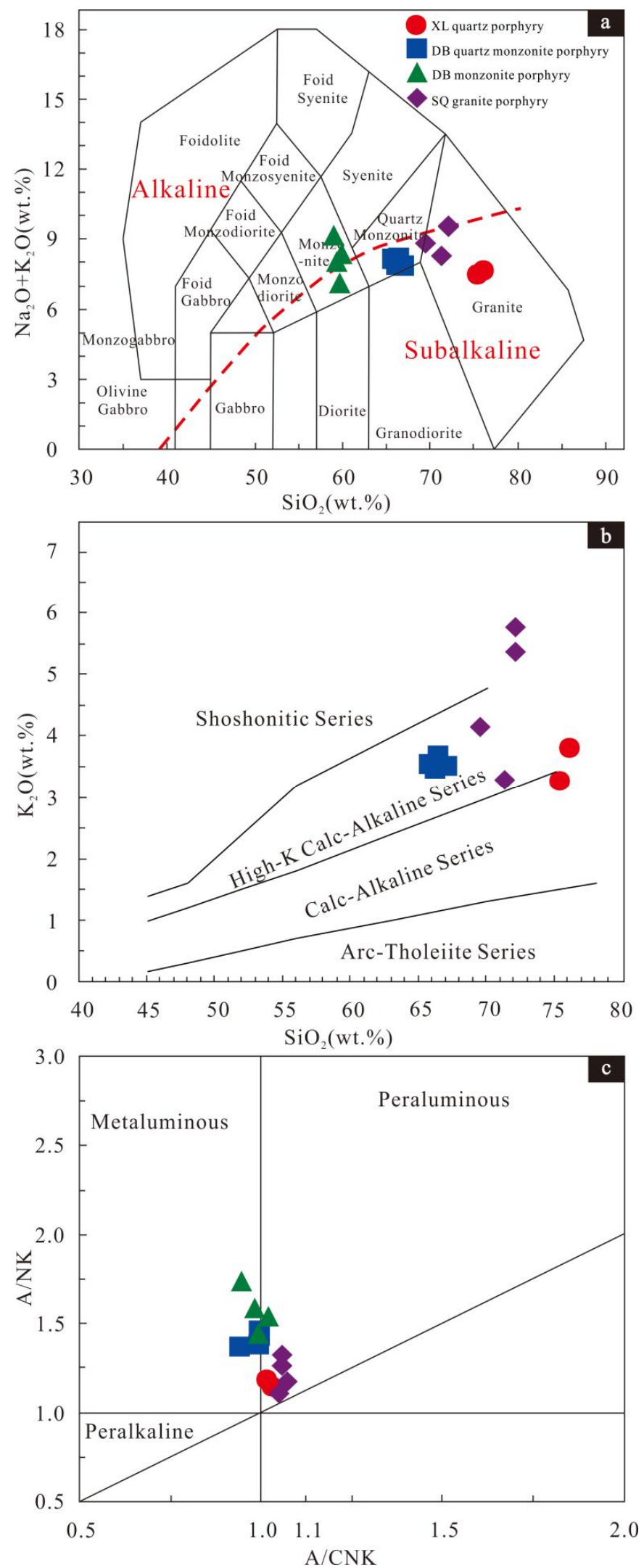

Figure 5. Classification diagrams for intrusive rocks in the study area: (a) TAS classification diagram (Middlemost [98] and Irvine and Baragar [99]); (b) $\mathrm{SiO}_{2}$ versus $\mathrm{K}_{2} \mathrm{O}$ diagram (Peccerillo and Taylor [100]); (c) A/CNK versus A/NK diagram (Maniar and Piccoli [101]). A/CNK: $\mathrm{Al}_{2} \mathrm{O}_{3} /(\mathrm{CaO}+$ $\left.\mathrm{Na}_{2} \mathrm{O}+\mathrm{K}_{2} \mathrm{O}\right) ; \mathrm{A} / \mathrm{NK}: \mathrm{Al}_{2} \mathrm{O}_{3} /\left(\mathrm{Na}_{2} \mathrm{O}+\mathrm{K}_{2} \mathrm{O}\right)$ (molar ratio). 

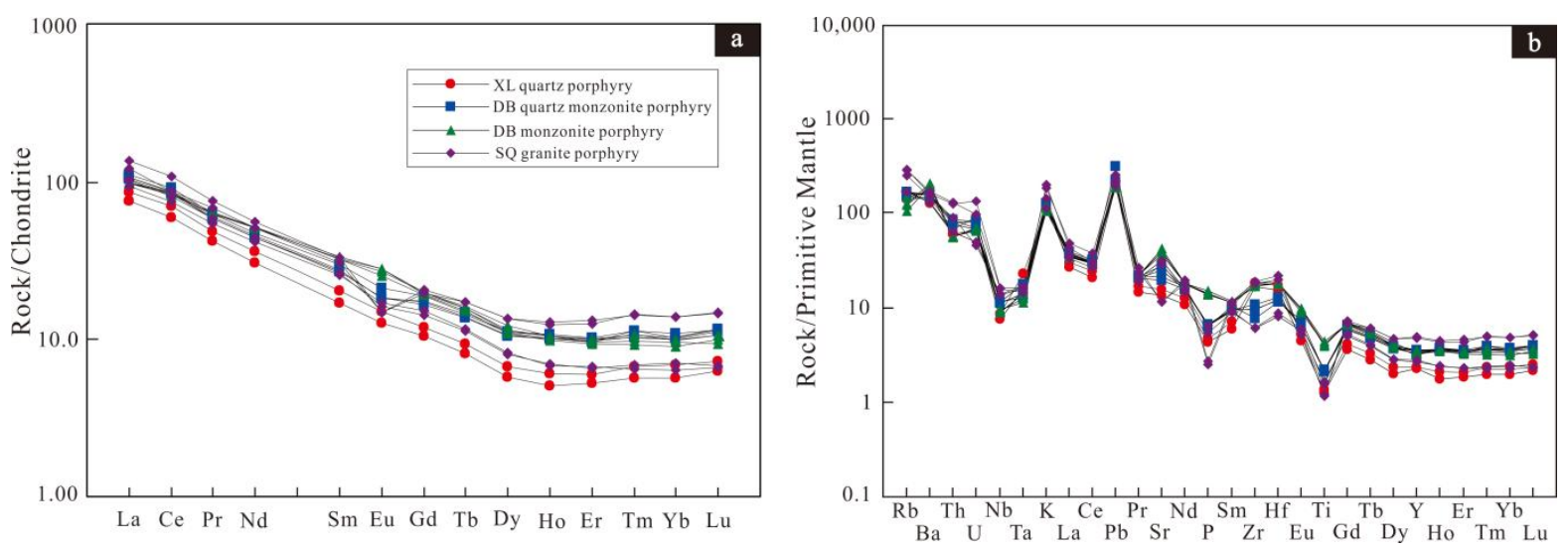

Figure 6. (a) Chondrite-normalized REE patterns, and (b) primitive mantle-normalized trace element spidergrams for the Early Cretaceous intrusive rocks in the study area. Chondrite-normalized and primitive mantle-normalized values are from Boynton [102] and Sun and McDonough [103], respectively.

The monzonite porphyry samples (DBD06, DBD07, DBD08, and DBD09) from the Dongbaolidagan area were characterized by $\mathrm{SiO}_{2}(59.01-59.83 \mathrm{wt} . \%$; average $59.45 \mathrm{wt} . \%)$, $\mathrm{Al}_{2} \mathrm{O}_{3}$ (17.14-18.67 wt.\%; average 17.74 wt.\%), $\mathrm{Na}_{2} \mathrm{O}$ (4.03-5.79 wt.\%; average 4.77 wt.\%), $\mathrm{K}_{2} \mathrm{O}$ (3.08-3.59 wt.\%; average 3.37 wt.\%), $\mathrm{K}_{2} \mathrm{O}+\mathrm{Na}_{2} \mathrm{O}$ (7.11-9.12 wt.\%; average 8.14 wt.\%), $\mathrm{K}_{2} \mathrm{O} / \mathrm{Na}_{2} \mathrm{O}$ (0.57-0.77), $\mathrm{MgO}\left(0.98-1.43\right.$ wt.\%), $\mathrm{CaO}$ (3.04-4.49 wt.\%), $\mathrm{P}_{2} \mathrm{O}_{5}(0.292-0.324$ wt.\%), $\mathrm{TiO}_{2}\left(0.84-0.93\right.$ wt.\%), $\mathrm{FeO}^{\mathrm{T}}\left(4.41-4.95\right.$ wt.\%), and $\mathrm{FeO}^{\mathrm{T}} / \mathrm{MgO}$ (3.21-4.72). From the total alkali $\mathrm{K}_{2} \mathrm{O}+\mathrm{Na}_{2} \mathrm{O}$ versus $\mathrm{SiO}_{2}$ diagram, with the Rittman index $(\sigma)$ of 3.03-5.19 (average 4.07), all samples were found to be in the field of monzonite and alkaline series (Figure 5a,b). The A/CNK values (0.95-1.03; average 0.99) suggested that these rocks belonged to the metaluminous rocks series (Figure $5 \mathrm{c}$ ). In the chondrite-normalized REE patterns, the samples had $\sum$ REE contents of 120.45-123.99 ppm with LREE/HREE values of 9.09-9.63 and $(\mathrm{La} / \mathrm{Yb})_{\mathrm{N}}$ ratios of 9.84-10.71, implying the modest fractionation of the LREE and HREE (Figure $6 \mathrm{a})$. All the samples hardly showed any Eu anomalies $(\delta \mathrm{Eu}=1.02-1.10$; average 1.07; Supplementary Table S2). Moreover, in the primitive mantle-normalized spider diagram (Figure $6 \mathrm{~b}$ ), these samples were characterized by relative enrichment in $\mathrm{Ba}$, $\mathrm{K}, \mathrm{Pb}, \mathrm{Sr}, \mathrm{Zr}$, and $\mathrm{Hf}$ content and obvious depletion in $\mathrm{Ti}, \mathrm{Nb}$, and $\mathrm{Ta}$ content.

The quartz porphyry samples (XLD03 and XLD04) from the Xielin area were characterized by $\mathrm{SiO}_{2}$ (75.26-75.96 wt.\%; average $\left.75.61 \mathrm{wt} . \%\right), \mathrm{Al}_{2} \mathrm{O}_{3}$ (11.99-12.42 wt.\%; average 12.21 wt.\%), $\mathrm{Na}_{2} \mathrm{O}$ (3.79-4.21 wt.\%; average $\left.4.00 \mathrm{wt.} \%\right), \mathrm{K}_{2} \mathrm{O}$ (3.27-3.81wt.\%; average 3.54 wt.\%), $\mathrm{K}_{2} \mathrm{O}+\mathrm{Na}_{2} \mathrm{O}$ (7.48-7.61 wt.\%; average 7.54 wt.\%), $\mathrm{K}_{2} \mathrm{O} / \mathrm{Na}_{2} \mathrm{O}(0.78-1.00), \mathrm{MgO}$ (0.43-0.45 wt.\%), $\mathrm{CaO}$ (0.66-0.97 wt.\%), $\mathrm{P}_{2} \mathrm{O}_{5}$ (0.092-0.100 wt.\%), $\mathrm{TiO}_{2}(0.28-0.30$ wt.\%), $\mathrm{FeO}^{\mathrm{T}}\left(1.71-1.77\right.$ wt.\%), and $\mathrm{FeO}^{\mathrm{T}} / \mathrm{MgO}(3.83-4.10)$. From the total alkali $\mathrm{K}_{2} \mathrm{O}+\mathrm{Na}_{2} \mathrm{O}$ versus $\mathrm{SiO}_{2}$ diagram and the $\mathrm{K}_{2} \mathrm{O}$ versus $\mathrm{SiO}_{2}$ diagram, with the Rittman index $(\sigma)$ of 1.73-1.76 (average 1.74), all samples were found to be in the field of granite and high-K calc-alkaline series, respectively (Figure $5 a, b)$. The A/CNK values (1.02-1.03; average 1.03) suggested that these rocks belonged to the weakly peraluminous rocks series (Figure $5 \mathrm{c}$ ). In the chondrite-normalized REE patterns, the samples had $\sum$ REE contents of 82.02-95.16 ppm with LREE/HREE values of 11.99-12.00 and $(\mathrm{La} / \mathrm{Yb})_{\mathrm{N}}$ ratios of 12.53-13.36, implying the modest fractionation of the LREE and HREE (Figure 6a). All the samples showed slightly negative Eu anomalies ( $\delta \mathrm{Eu}=0.95-0.96$; average 0.96; Supplementary Table S2). Moreover, in the primitive mantle-normalized spider diagram (Figure 6b), these samples were characterized by relative enrichment in $\mathrm{Ba}, \mathrm{K}, \mathrm{Pb}$, and $\mathrm{Hf}$ content and obvious depletion in $\mathrm{Nb}$, $\mathrm{Ta}, \mathrm{P}$, and Ti content.

The granite porphyry samples (SQD11, SQD12, SQD13, and XLD04) from the Shuiquan area were characterized by $\mathrm{SiO}_{2}(69.44-72.03 \mathrm{wt} . \%$; average $71.17 \mathrm{wt} . \%), \mathrm{Al}_{2} \mathrm{O}_{3}(14.27-16.00 \mathrm{wt} . \%$; average $14.92 \mathrm{wt}$ \%), $\mathrm{Na}_{2} \mathrm{O}$ (3.73-4.97 wt.\%; average $\left.4.37 \mathrm{wt} . \%\right), \mathrm{K}_{2} \mathrm{O}(3.29-5.79 \mathrm{wt} . \%$; average 4.65 wt.\%), $\mathrm{K}_{2} \mathrm{O}+\mathrm{Na}_{2} \mathrm{O}$ (8.26-9.55 wt.\%; average 9.03 wt.\%), $\mathrm{K}_{2} \mathrm{O} / \mathrm{Na}_{2} \mathrm{O}$ (0.66-1.55), $\mathrm{MgO}$ (0.30-0.50 wt.\%), $\mathrm{CaO}\left(0.51-1.66\right.$ wt.\%), $\mathrm{P}_{2} \mathrm{O}_{5}$ (0.054-0.138 wt.\%), $\mathrm{TiO}_{2}\left(0.25-0.35\right.$ wt.\%), $\mathrm{FeO}^{\mathrm{T}}$ 
(1.83-2.01 wt.\%), and $\mathrm{FeO}^{\mathrm{T}} / \mathrm{MgO}$ (3.85-6.71). From the total alkali $\mathrm{K}_{2} \mathrm{O}+\mathrm{Na}_{2} \mathrm{O}$ versus $\mathrm{SiO}_{2}$ diagram and the $\mathrm{K}_{2} \mathrm{O}$ versus $\mathrm{SiO}_{2}$ diagram, with the Rittman index $(\sigma)$ of 2.42-3.15 (average $4.07)$, all samples were found to be in the field of granite and high-K calc-alkaline series to shoshonitic series, respectively (Figure 5a,b). The A/CNK values (1.05-1.07; average 1.06) suggested that these rocks belonged to the weakly peraluminous rocks series (Figure $5 \mathrm{c}$ ). In the chondrite-normalized REE patterns, the samples had $\sum$ REE contents of 105.70-150.75 ppm with LREE/HREE values of 8.47-12.49 and $(\mathrm{La} / \mathrm{Yb})_{\mathrm{N}}$ ratios of 8.72-14.63, implying the modest fractionation of the LREE and HREE (Figure 6a). All the samples showed negative Eu anomalies ( $\delta \mathrm{Eu}=0.57-0.86$; average 0.72; Supplementary Table S2). Moreover, in the primitive mantle-normalized spider diagram (Figure $6 \mathrm{~b}$ ), these samples were characterized by relative enrichment in $\mathrm{Rb}, \mathrm{Ba}, \mathrm{K}$, and $\mathrm{Pb}$ content and obvious depletion in $\mathrm{Nb}, \mathrm{Ta}, \mathrm{P}$, and Ti content.

\subsection{Zircon Hf Isotopes}

Five representative zircon grains were chosen from the DBT01, DBT02, XLT01, and SQT01 samples from the northern Ulanhot area for in situ Hf isotopic analyses (Supplementary Table S3).

The magmatic zircons of the quartz monzonite porphyry sample DBT01 had initial ${ }^{176} \mathrm{Hf} /{ }^{177} \mathrm{Hf}$ ratios of $0.282903-0.282937, \varepsilon_{\mathrm{Hf}}(\mathrm{t})$ values of +7.25 to +8.48 (average +7.82 ), and two-stage model ages $\left(\mathrm{T}_{\mathrm{DM} 2}\right)$ of $641-722 \mathrm{Ma}$.

The magmatic zircons of the monzonite porphyry sample DBT02 had initial ${ }^{176} \mathrm{Hf} /{ }^{177} \mathrm{Hf}$ ratios of $0.282923-0.282982$, $\varepsilon_{\mathrm{Hf}}(\mathrm{t})$ values of +8.05 to +10.10 (average +9.04 ), and two-stage model ages $\left(\mathrm{T}_{\mathrm{DM} 2}\right)$ of $538-670 \mathrm{Ma}$.

The magmatic zircons of the quartz porphyry sample XLT01 had initial ${ }^{176} \mathrm{Hf} /{ }^{177} \mathrm{Hf}$ ratios of $0.282977-0.283020, \varepsilon_{\mathrm{Hf}}(\mathrm{t})$ values of +9.83 to +11.35 (average +10.37 ), and twostage model ages $\left(\mathrm{T}_{\mathrm{DM} 2}\right)$ of 453-552 Ma. However, one of the magmatic zircons had an initial ${ }^{176} \mathrm{Hf} /{ }^{177} \mathrm{Hf}$ ratio of 0.283161 and an abnormal $\varepsilon_{\mathrm{Hf}}(\mathrm{t})$ value of +16.31 ; this was thus invalid data.

The magmatic zircons of the granite porphyry sample SQT01 had initial ${ }^{176} \mathrm{Hf} /{ }^{177} \mathrm{Hf}$ ratios of $0.282912-0.282968, \varepsilon_{\mathrm{Hf}}(\mathrm{t})$ values of +7.57 to +9.51 (average +8.22 ), and two-stage model ages $\left(\mathrm{T}_{\mathrm{DM} 2}\right)$ of $574-697 \mathrm{Ma}$.

The Hf isotopic characteristics of zircons from these intrusive rocks were relatively consistent with those of zircons from the Late Mesozoic granitoids in the GXR (Figure 7a,b).
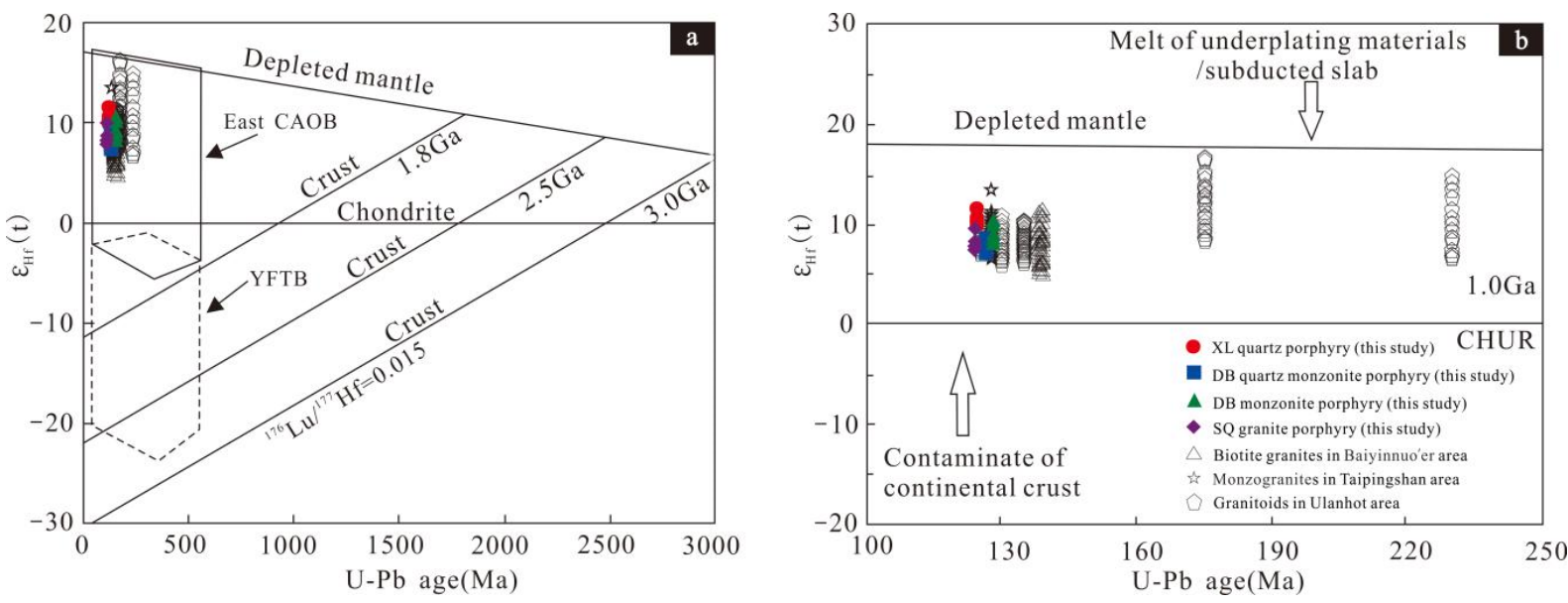

Figure 7. Zircon Hf isotopic composition of the Early Cretaceous intrusive rocks in the northern part of Ulanhot area. (a) $\varepsilon_{\mathrm{Hf}}(\mathrm{t})$ versus $\mathrm{U}-\mathrm{Pb}$ age (Ma) diagram; (b) the detailed distribution of samples in the $\varepsilon_{\mathrm{Hf}}(\mathrm{t})$ versus $\mathrm{U}-\mathrm{Pb}$ age $(\mathrm{Ma})$ diagram. CAOB: Central Asian Orogenic Belt; YFTB: Yanshan Fold and Thrust Belt (Yang et al. [104]). $\varepsilon$ Hf (t) values of the granitoids in the Ulanhot, Taipingshan, and Baiyinnuo'er areas are from Zhou et al. [23], Lu et al. [64], and Wei et al. [18], respectively. 


\section{Discussion}

\subsection{Timing of Intrusive Rocks}

Previous studies have shown that the tectonic magmatic activities from the Paleozoic to the Mesozoic in the GXR were frequent and complex [55,72], especially marked by the large-scale outcropping of Late Mesozoic granitic rocks (Figure 1c) [8,18,26,38,71,105-107]. Numerous geochronological data indicate that the magmatic activities in the GXR area reached a peak during the Early Cretaceous, with the formation age of the granitic rocks ranging from 140 to $125 \mathrm{Ma}$ (Supplementary Table S4; Figure 8) [2,14,19,23,108]. However, these studies were mainly focused on the northern and southern parts of the GXR $[5-7,20,24,26,32,34,35,57,63]$ and few have focused on the central-southern segment $(1,16,17,64)$. In this study, we selected intrusive rock samples (DBT01, DBT02, XLT01, and SQT01) from the northern Ulanhot area in the central-southern GXR for the first time to conduct high-precision zircon $\mathrm{U}-\mathrm{Pb}$ age testing (Figure 2), and it was concluded that the crystallization ages of these rocks were approximately 128-124 Ma (Figure 4). These results were basically harmonious with the zircon ages for granitoids in the central-southern GXR and adjacent areas (Figure 8) and were in accordance with the main stage of the Early Cretaceous tectonomagmatism and lithospheric thinning in GXR, NE China $[4,16,17,25,29,35]$. It is also the main metallogenic period of medium- to large-scale $\mathrm{Pb}-\mathrm{Zn}$ - $\mathrm{Ag}$ and Mo deposits $[24,26,28,32,108,109]$.

\subsection{Petrogenesis and Magma Source of Intrusive Rocks}

\subsubsection{Monzonite Porphyry}

The monzonite porphyry samples were characterized by high $\mathrm{Al}_{2} \mathrm{O}_{3}(17.14-18.67 \mathrm{wt} . \%$; average $17.74 \mathrm{wt.} \%$ ) and $\mathrm{K}_{2} \mathrm{O}+\mathrm{Na}_{2} \mathrm{O}(7.11-9.12 \mathrm{wt} . \%$; average $8.14 \mathrm{wt} . \%)$ content and low $\mathrm{SiO}_{2}$ (59.01-59.83 wt.\%; average 59.45 wt.\%), $\mathrm{MgO}$ (0.98-1.43 wt.\%), $\mathrm{CaO}$ (3.04-4.49 wt.\%), and $\mathrm{P}_{2} \mathrm{O}_{5}(0.292-0.324 \mathrm{wt} . \%)$ content; they belonged to alkaline series rocks (Figure $5 b$ ), suggesting an extensional geological setting. There are several models of the origin of alkaline rocks: (a) crystallization differentiation of alkaline basalt magma derived directly from the mantle [110,111]; (b) partial melting of materials in the lower crust [112,113]; and (c) magmatic mixing of mantle-derived magma and crust-derived magma [114].

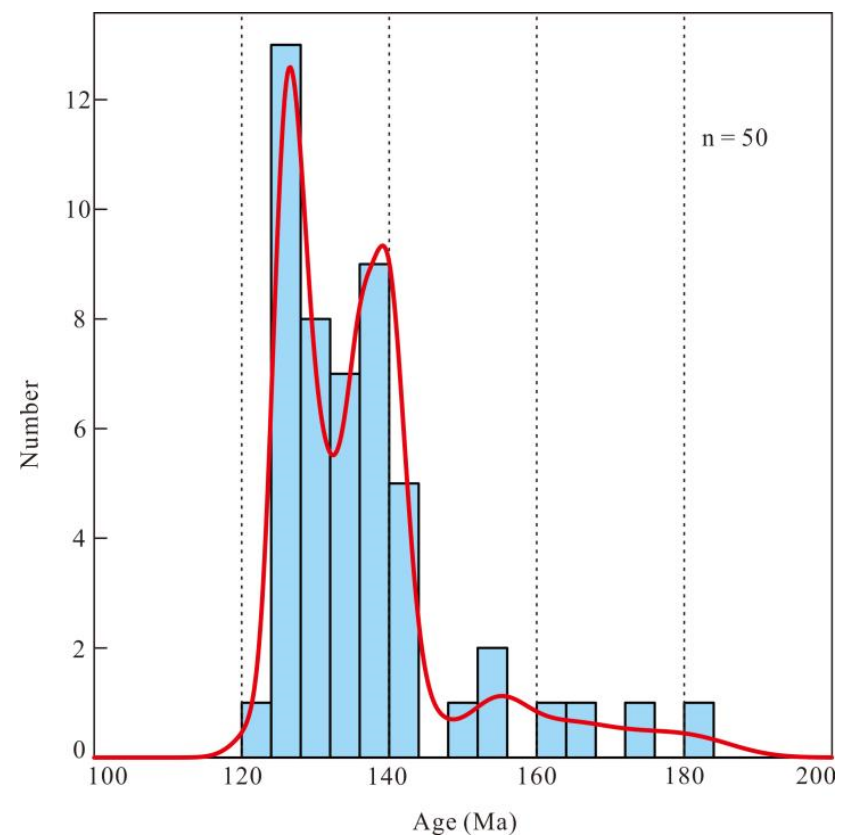

Figure 8. Zircon ages for granitoids in the central-southern Great Xing'an Range and adjacent areas (ages data cited from Supplementary Table S4). 
The samples showed low Ni (2.61-8.09 ppm; average 4.63 ppm), Cr (6.21-7.29 ppm; average $6.69 \mathrm{ppm})$, and $\mathrm{Mg}^{\#}$ (27.61-35.89; average 31.11) content but high $\mathrm{TiO}_{2}(0.84-0.93$ wt.\%; average $0.88 \mathrm{wt} \%$ ) content, which was inconsistent with high $\mathrm{Ni}$ (300-400 ppm), $\mathrm{Cr}$ (50-300 ppm), and $\mathrm{Mg}^{\#}$ (>60) content and low $\mathrm{TiO}_{2}(<0.50 \mathrm{wt} . \%)$ content geochemical characteristics of the mantle-derived magma [115,116], suggesting that these rocks were not from the mantle magma. Furthermore, due to the absence of mafic or ultramafic accumulation, it is ruled out that these rocks were derived from an extreme differentiation pattern of mantle-derived magma [34,117]. Conversely, these rocks were relatively enriched in $\mathrm{Ba}, \mathrm{K}, \mathrm{Pb}, \mathrm{Sr}, \mathrm{Zr}$, and $\mathrm{Hf}$ and depleted in $\mathrm{Ti}, \mathrm{Nb}$, and $\mathrm{Ta}$, implying the possibility of crustderived magma with the magma characteristics of island arc or active continental margin arc [118,119]. Moreover, the $\mathrm{Ce} / \mathrm{Pb}$ (3.64-3.93), Nb/U (4.66-4.74), Nd/Th (5.03-5.22), and $\mathrm{La} / \mathrm{Nb}(3.44-3.70)$ values of the samples were more similar to those of crustal rocks $(4,10$, 3 , and 2.2, respectively) than the primitive mantle $(9,30,15$, and 0.94 , respectively), further elucidating the origin of crustal magma [87,120,121]. In addition, the magmatic zircons of the monzonite porphyry had initial ${ }^{176} \mathrm{Hf} /{ }^{177} \mathrm{Hf}$ ratios of $0.282923-0.282982$, $\varepsilon_{\mathrm{Hf}}(\mathrm{t})$ values of +8.05 to +10.10 (average +9.04 ), and two-stage model ages $\left(\mathrm{T}_{\mathrm{DM} 2}\right)$ of $538-670 \mathrm{Ma}$ (Figure $7 a, b)$, indicating that the magma sources of the samples had the quality of juvenile crustal materials, which were accreted during the Neoproterozoic [53]. Additionally, it is worth noting that the $\mathrm{Eu}(\delta \mathrm{Eu}=1.02-1.10$; average 1.07) anomalies of these rocks were not prominent, with lower contents of $Y(14.4-16.1 \mathrm{ppm}$; average $15.16 \mathrm{ppm})$ and $\mathrm{Yb}$ (1.53-1.68 ppm; average $1.62 \mathrm{ppm}$ ), suggesting that the rocks were derived from the partial melting of the lower crust at high pressure with the garnet residue instead of the plagioclase residue in the source area [122-124]. Therefore, we propose that the monzonite porphyry in the Ulanhot area is the product of partial melting of juvenile crustal materials at high pressure.

\subsubsection{Granitic Rocks}

The quartz monzonite porphyry, quartz porphyry, and granite porphyry samples from the Ulanhot area exhibit high $\mathrm{SiO}_{2}$ content (average $66.27 \mathrm{wt} \%$, average $71.17 \mathrm{wt} . \%$, and average $75.61 \mathrm{wt} . \%$, respectively) and low $\mathrm{Al}_{2} \mathrm{O}_{3}$ content (average $15.62 \mathrm{wt} . \%$, average $14.92 \mathrm{wt} . \%$, and average $12.21 \mathrm{wt} \%$, respectively), pertaining to the category of high-K calc-alkaline rocks $(\sigma<3.3$; Supplementary Table S2) and acid granitic rocks. In general terms, granitic rocks are classified into S-, I-, and A-types based on the characteristics of provenance and geochemistry [125-128]. S-type granite shows high A/CNK values (>1.1) and the presence of cordierite, garnet, and muscovite minerals, which are mainly derived from metamorphic sedimentary source rocks [125]. In this work, the A/CNK values of granitic rocks samples from the Ulanhot area were 0.95-1.00, 1.02-1.03, and 1.05-1.07 for quartz monzonite porphyry, quartz porphyry, and granite porphyry, respectively, notably lower than the standard values of S-type granite $(\mathrm{A} / \mathrm{CNK}>1.1)$. Simultaneously, the low content of $\mathrm{P}_{2} \mathrm{O}_{5}$ (Supplementary Table S2) and the absence of cordierite, garnet, and muscovite minerals (Figure 3d) precludes the probability of S-type granite [129,130]. In addition, the experimental petrology showed that for the metaluminous to weakly peraluminous rocks, the solubility of $\mathrm{P}$ in I-type granite melts decreased with an increase in $\mathrm{SiO}_{2}$ content and exhibited a negative correlation between $\mathrm{P}_{2} \mathrm{O}_{5}$ and $\mathrm{SiO}_{2}$ [131], whereas the strongly peraluminous S-type granites showed no such trend [132]. In the Harker diagram (Figure 9f), these granitic rocks showed a negative correlation between $\mathrm{P}_{2} \mathrm{O}_{5}$ and $\mathrm{SiO}_{2}$, further verifying the prototypical properties of I-type granites rather than $\mathrm{S}$ type granites [129], which are consistent with the $\mathrm{K}_{2} \mathrm{O}$ versus $\mathrm{Na}_{2} \mathrm{O}$ diagram (Figure 10f). A-type granite belongs to an alkaline series formed at high temperature $\left(840{ }^{\circ} \mathrm{C}\right.$; King et al. [113]) and is characterized by high $\mathrm{FeO}^{\mathrm{T}} / \mathrm{MgO}, 10,000 \times \mathrm{Ga} / \mathrm{Al}$, and $(\mathrm{Zr}+\mathrm{Nb}$ $+\mathrm{Ce}+\mathrm{Y}$ ) values $[128,133]$. From the results of the total alkali $\mathrm{K}_{2} \mathrm{O}+\mathrm{Na}_{2} \mathrm{O}$ versus $\mathrm{SiO}_{2}$ diagram, these granitic rocks fell into the subalkaline field (Figure 5a). The zircon saturation temperatures of these rocks $\left(727-821^{\circ} \mathrm{C}\right.$; average $774{ }^{\circ} \mathrm{C}$; Supplementary Table S2) were significantly lower than those of A-type granites $\left(840^{\circ} \mathrm{C}\right)$ and more similar to those of 
I-type granites $\left(764{ }^{\circ} \mathrm{C}\right.$; King et al. [113]) [134]. Meanwhile, the samples displayed low $\mathrm{FeO}^{\mathrm{T}} / \mathrm{MgO}$ (3.04-6.71; average 4.12, lower than 10), $\left.\mathrm{Zr}+\mathrm{Nb}+\mathrm{Ce}+\mathrm{Y}\right)(135.80-304.64$ ppm; average 207.55, lower than $350 \mathrm{ppm})$, and 10,000 $\times \mathrm{Ga} / \mathrm{Al}$ (2.19-2.78; average 2.39, lower than 2.6), suggesting that the granitic rocks have an affinity for I-type granite instead of A-type granite $[128,133,135]$, which is also in line with the diagrams of discriminate genesis of the intrusive rocks (Figure 10). Therefore, we consider that the Early Cretaceous quartz monzonite porphyry, quartz porphyry, and granite porphyry rocks in the Ulanhot area have an affinity for I-type granites.
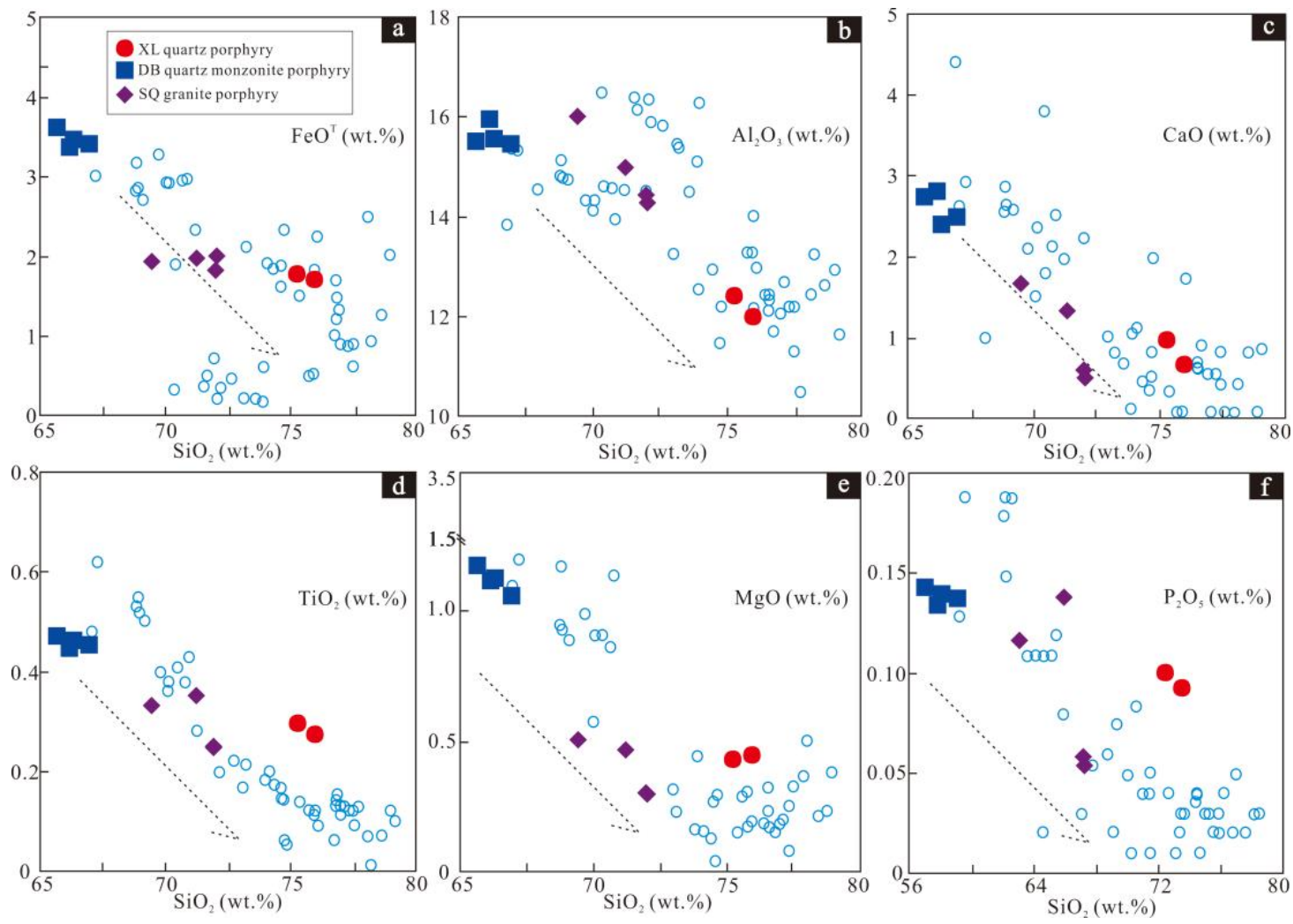

Figure 9. Harker diagrams showing content variation of major elements (modified after Wei et al. [18] and references therein). (a) $\mathrm{FeO}^{\mathrm{T}}$ versus $\mathrm{SiO}_{2}$ diagram; (b) $\mathrm{Al}_{2} \mathrm{O}_{3}$ versus $\mathrm{SiO}_{2}$ diagram; (c) $\mathrm{CaO}$ versus $\mathrm{SiO}_{2}$ diagram; (d) $\mathrm{TiO}_{2}$ versus $\mathrm{SiO}_{2}$ diagram; (e) $\mathrm{MgO}$ versus $\mathrm{SiO}_{2}$ diagram; (f) $\mathrm{P}_{2} \mathrm{O}_{5}$ versus $\mathrm{SiO}_{2}$ diagram.

However, the material sources of I-type granites have been debated [12,13]. Several models have been used to explain the genesis of I-type granite, suggesting it is generated by: (1) fractional crystallization of the mixed magmas formed by mantle-derived mafic magmas and felsic magmas [136]; (2) direct fractionation crystallization of mantle-derived mafic magmas [137]; and (3) partial melting and crystal fractionation of the lower crustal rocks after the intrusion of mafic magmas [135]. 

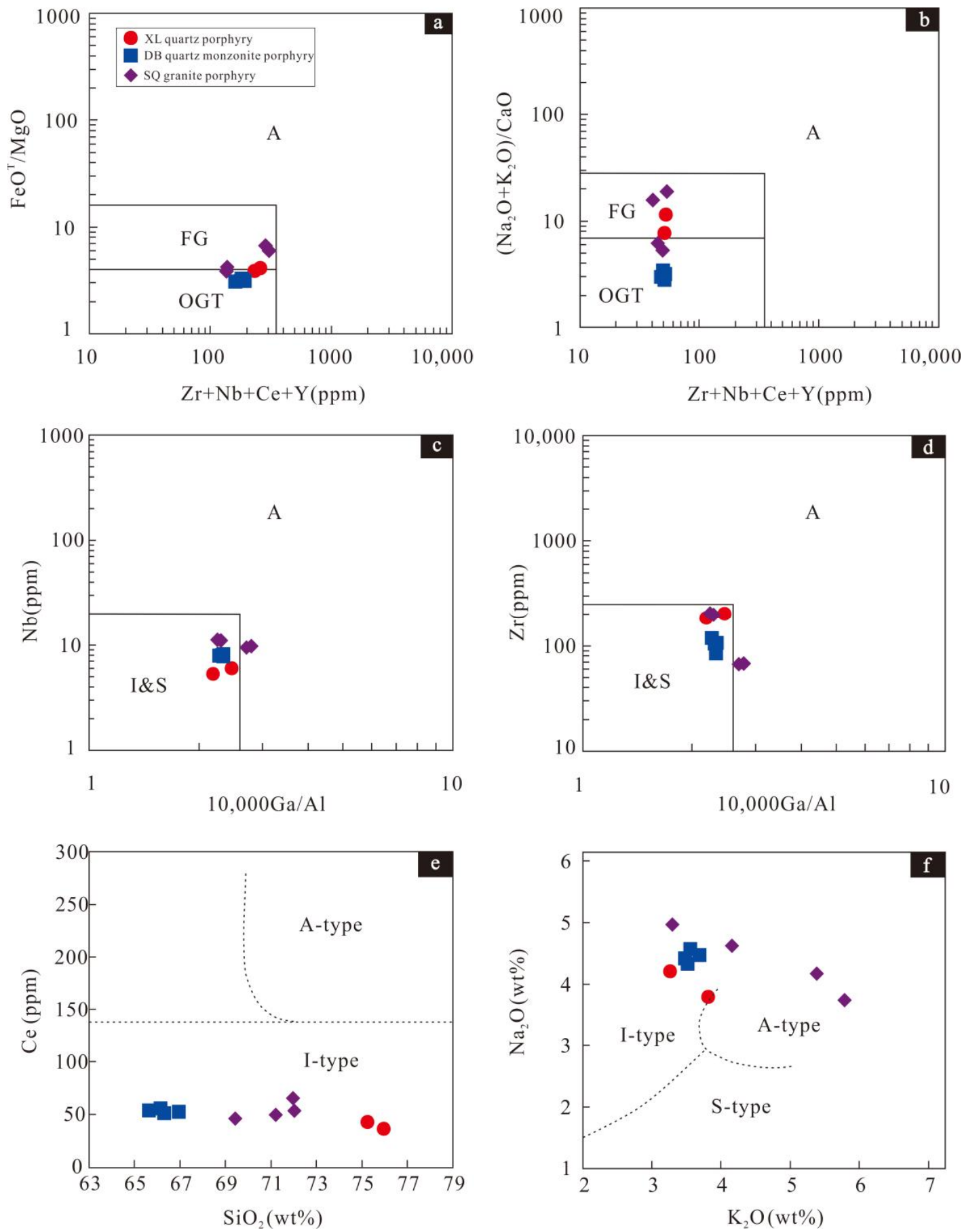

Figure 10. Diagram of discriminate genesis of intrusive rocks in the study area: (a) $\mathrm{SiO}_{2}$ versus $\mathrm{FeO}^{\mathrm{T}} /\left(\mathrm{FeO}^{\mathrm{T}}+\mathrm{MgO}\right)$ diagram (Whalen et al. [128]); (b) $(\mathrm{Zr}+\mathrm{Y}+\mathrm{Nb}+\mathrm{Ce})$ versus $\left(\mathrm{Na}_{2} \mathrm{O}+\mathrm{K}_{2} \mathrm{O}\right) / \mathrm{CaO}$ diagram (Whalen et al. [128]); (c) $(10,000 \times$ $\mathrm{Ga} / \mathrm{Al}$ ) versus $\mathrm{Nb}$ diagram (Whalen et al. [128]); (d) $(10,000 \times \mathrm{Ga} / \mathrm{Al}$ ) versus $\mathrm{Zr}$ diagram (Whalen et al. [128]); (e) $\mathrm{SiO} 2$ versus Ce diagram (Collins [126]); (f) $\mathrm{K}_{2} \mathrm{O}$ versus $\mathrm{Na}_{2} \mathrm{O}$ diagram (Collins [126]).

The granitic rocks exhibited high $\mathrm{SiO}_{2}$ content (>66 wt.\%) and low $\mathrm{MgO}$ (average 0.69 wt. \%), $\mathrm{Mg}^{\#}$ (average $31.49 \mathrm{ppm}$ ), Ni (average $2.78 \mathrm{ppm}$ ), and $\mathrm{Cr}$ (average $8.10 \mathrm{ppm}$ ) content, suggesting that these rocks were not from the mantle magma $[115,116]$. Furthermore, the undiscovered mafic microgranular enclaves [138] and the few variations in $\varepsilon_{\mathrm{Hf}}(t)$ values (Supplementary Table S3) [34] suggest that the mixed magma model is insufficient for the formation of the Ulanhot granitic rocks. These granitic rock samples had low $\Sigma$ REE values (82.02-150.75; average 116.43), LREE/HREE values (8.47-12.49; average 10.47), and 
$(\mathrm{La} / \mathrm{Yb})_{\mathrm{N}}$ values $(8.72-14.63$; average 11.47), with apparent depletion of $\mathrm{Nb}, \mathrm{Ta}, \mathrm{P}$, and $\mathrm{Ti}$, indicating the characteristics of crust-derived magmas [139]. The $\mathrm{Zr} / \mathrm{Hf}$ (24.24-39.33; average 30.62) and $\mathrm{Nb} / \mathrm{Ta}(6.59-18.89$; average 13.59) values approached the crust values (33 and 11, respectively) and were lower than those of the primitive mantle (37 and 17.8, respectively) [103]. Moreover, the $\mathrm{Ce} / \mathrm{Pb}$ (2.47-4.00; average 3.28), $\mathrm{Nb} / \mathrm{U}$ (3.26-10.49; average 5.80), $\mathrm{Nd} / \mathrm{Th}$ (2.22-4.00; average 2.97), and $\mathrm{La} / \mathrm{Nb}$ (2.26-3.37; average 2.95) values of the samples were more similar to those of the crustal rocks $(4,10,3$, and 2.2 , respectively) than to those of the primitive mantle $(9,30,15$, and 0.94 , respectively) $[103,120,121]$. In addition, the $\varepsilon_{\mathrm{Hf}}(\mathrm{t})$ values $(+7.25$ to +11.35$)$ and $\mathrm{T}_{\mathrm{DM} 2}$ ages (453-722 Ma) of zircons within this research (Supplementary Table S3; Figure 7a,b) show that the magma sources of the samples also had the essential property of juvenile crustal materials. Significantly, the La versus La/Sm diagram (Figure 11a) showed that conspicuously fractional crystallization occurred during the emplacement process of magma. The granitic rock samples of the Ulanhot area were characterized by $\mathrm{Nb}, \mathrm{Ta}, \mathrm{P}$, and Ti depletion and negative Eu anomalies $(\delta \mathrm{Eu}=0.57-0.96$; average 0.82; Supplementary Table S2; Figure 6$)$, suggesting that the crustderived magmas may be accompanied by fractional crystallization of plagioclase, titanite, and apatite minerals in the process of ascending emplacement at low pressure $[139,140]$, which is consistent with the Harker diagrams (Figure 9) and $\mathrm{Sr}$ versus $\mathrm{Ba} / \mathrm{Sr}$ diagram (Figure 11b). Thus, we propose that the primary magmas of the granitic rocks in the study area were derived from the partial melting of juvenile crustal rocks at low pressure, accompanied by strong plagioclase fractional crystallization.
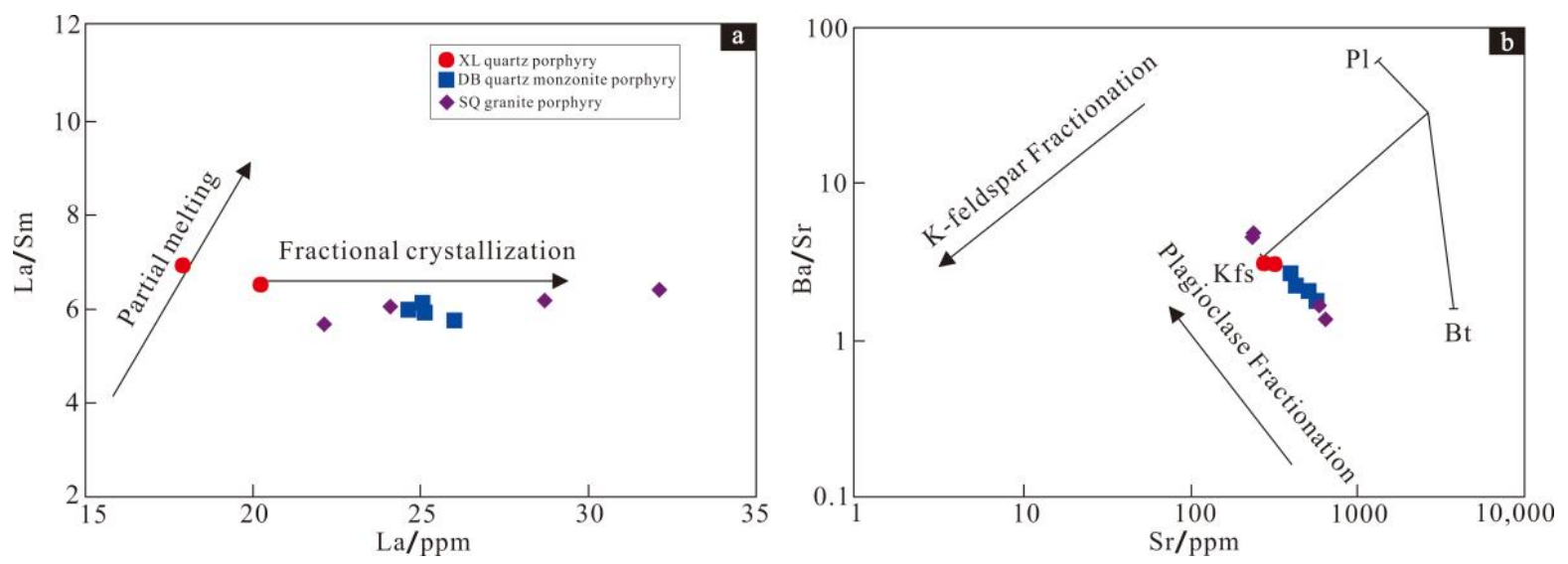

Figure 11. Diagrams of (a) La versus La/Sm; (b) Sr versus Ba/Sr. Pl- plagioclase; Kfs- K-feldspar; Bt-biotite.

\subsection{Tectonic Implications}

As mentioned earlier, the Ulanhot intrusive rocks consist of alkaline monzonite porphyry and highly fractionated I-type granites (e.g., quartz monzonite porphyry, quartz porphyry, and granite porphyry rocks) and are the consequence of tectonic magmatic events during the Early Cretaceous (ca. 128-124 Ma). It is generally considered that the tremendous volcanic and plutonic rocks distributed in the GXR are the products of the lithospheric thinning events that occurred during the Early Cretaceous in eastern China $[2,7,8,53,60]$. However, the geodynamic setting of these large-scale NNE-trending plutonic rocks in the GXR is still in dispute, mainly focusing on the following models: (1) the upwelling magmas associated with the mantle plume [9,46]; (2) a post-collision gravitational collapse of the Mongol-Okhotsk Ocean plate [30,47-52,74,141]; (3) lithospheric delamination induced by the contribution of westward subduction of the Paleo-Pacific slab [53-56]; and (4) retreat of the PPO plate and the succedent upwelling of the varying degrees of the asthenosphere mantle $[4,8,35,57-60]$.

The model of upwelling magmas associated with mantle plumes generally showed a circular-shaped distribution of igneous rocks, and the duration of magmatic eruption was only a few million years [142], which were broadly inconsistent with the NNE-trending 
linear distribution of Early Cretaceous granites and the duration of magmatism of approximately $40 \mathrm{Ma}$ in the GXR area [35,38]; therefore, it was excluded. Previous studies have revealed that from the Early Mesozoic to Late Jurassic, the Mongol-Okhotsk Ocean plate underwent a long descent into closure [17,34], and through a scissor-like mode from west to east eventually led to closures in the Amur region. [26,49,74,143]. Furthermore, the NE tendency of the Mongol-Okhotsk Ocean suture zone did not correspond to the NNE direction of the GXR main ridge, indicating that the Mongol-Okhotsk Ocean tectonic domain probably failed to efficaciously control the Early Cretaceous magmatism in the GXR area [4,8]. With the development of geological and tectonic evolution of NE China, an increasing number of studies have revealed that the PPO plate was already subducted to the Eurasia prior to the Early Jurassic $[8,24,35,45,57,61,144]$, including those on the Nadanhada accretionary complex in NE China [144], which effectively recorded the incipient subduction of the PPO plate during the Late Triassic. Meanwhile, as the main body of the Nadanhada accretionary complex, the Raohe accretionary complex was formed by the continuous subduction of the PPO plate to the Eurasian continent, with abundant terrigenous debris and oceanic crust fragments mixed and accumulated in the trench during the Middle Jurassic to Early Cretaceous [145]. Geophysical evidence also suggests that the PPO plate subducted westward to the GXR region in the late Jurassic [56], which is consistent with the opinion that the PPO subduction plate front is in the mantle transition zone east of the GXR gravity gradient zone [62]. In addition, Ji et al. [59] considered that the PPO plate had already been subducted to the northern GXR by the occurrence of low-K adakitic lavas (ca. 163Ma) in the Hailar Basin, and the basin was in an extensional regime associated with the subducted PPO plate during the Early Cretaceous [57], confirming that the Mongol-Okhotsk Ocean plate had limited influence on the magma evolution of the GXR during the Early Cretaceous. Notably, the subduction mode of the PPO plate was a complex multi-stage and multidirectional evolution process $[1,8,61,72,75,146,147]$. With the subduction direction and velocity turnaround [148], the emplacement age of Early Cretaceous volcanic and plutonic rocks in NE China show a younger tendency from west to east stage by stage $[55,57]$, indicating that the retreat of the subducted PPO plate occurred during the Early Cretaceous [35,45,76], and the lithospheric delamination model induced by the subduction of the PPO plate is insufficient to explain the formation of the Early Cretaceous magmatism in the GXR area. New research has declared that during the 130-120 Ma period, the PPO plate changed into a high-angle subduction mode at a maximum receding rate and eventually formed the residual material, which was generated in the mantle transition zone [4]. In addition, at this stage, the Tan-Lu Fault Zone experienced a variation from a north-south compressional strike-slip environment to a strong extensional environment $[60,149]$. All the above lines indicate that the retreat of the PPO plate restrained the tectonic magmatism of the GXR during the Early Cretaceous. In this study, according to the $(\mathrm{La} / \mathrm{Nb})$ versus $(\mathrm{Ba} / \mathrm{Nb})$ diagram (Figure 12a) [150] and $\mathrm{Zr}$ versus $(\mathrm{Nb} / \mathrm{Zr}$ ) diagram (Figure $12 \mathrm{~b})$ [151], the monzonite porphyry samples were plotted in the field of arc igneous and subduction zones, suggesting an oceanic plate subduction environment. In the $(Y+N b)$ versus $R b$ and $(Y+T a)$ versus $R b$ diagrams (Figure 12c,d) [152], the granitic rock samples fell into the VAG field and showed a tendency of transition to intraplate granite. Moreover, the exposure of metamorphic core complexes in the Harkin and Ganzhuermiao areas [51,52], the extensional strike-slip of the Nenjiang-Balihan fault $[78,80,81]$, and the widespread distribution of A-type granites in the GXR area during the Early Cretaceous $[18,20,63]$ suggest that the study area was in an extensional tectonic environment. 

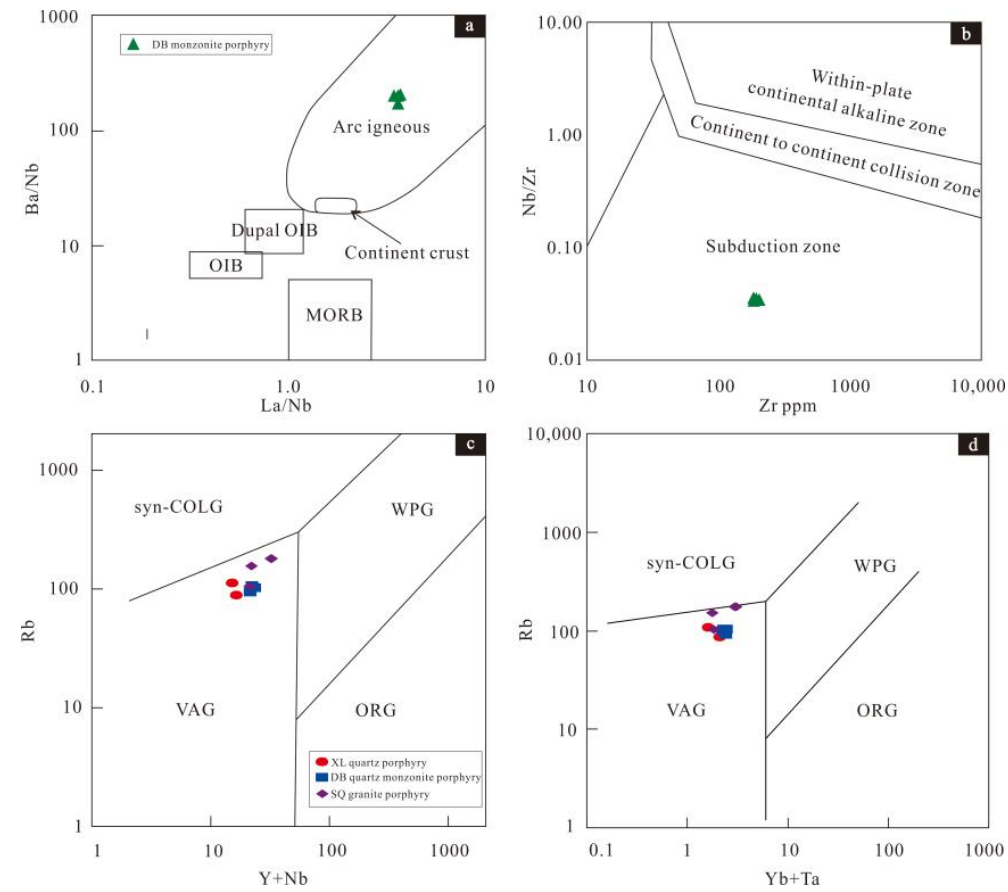

Figure 12. Tectonic discrimination diagrams for the Early Cretaceous intrusive rocks. (a) (La/Nb) versus (Ba/Nb) diagram (Jahn et al. [150]); (b) Zr versus (Nb/Zr) diagram (Luchitskaya et al. [151]); (c) $(\mathrm{Y}+\mathrm{Nb}$ ) versus $\mathrm{Rb}$ diagram (Pearce et al. [152]); (d) ( $\mathrm{Yb}+\mathrm{Ta}$ ) versus Rb diagram (Pearce et al. [152]). Abbreviations: VAG: volcanic arc granite; Syn COLG: syn-collisional granite; WPG: within-plate granite; ORG: ocean ridge granite.

In summary, the Ulanhot area was in an extensional tectonic background during the Early Cretaceous, and the formation of intrusive rocks was closely related to the retreat of the PPO subducted plate $[4,16,18,23,24,32,35,55,57,64,76]$. According to the experimental petrological data, the plagioclase residue in the magma source suggests that the magmas were derived from a low-pressure environment, whereas the garnet residue represented a high-pressure environment $[67,124]$. The residual plagioclase in the magma source indicates that the magmas were generated at a depth of approximately $40 \mathrm{~km}(<1.2 \mathrm{GPa})$ [122]. The monzonite porphyry (ca. $128 \mathrm{Ma})$ had low $\mathrm{Y}$ and $\mathrm{Yb}$ contents, and the $\mathrm{Eu}(\delta \mathrm{Eu}=1.02-1.10$; average 1.07) anomalies of these rocks were not prominent, suggesting the presence of the garnet residue in the monzonite porphyry and a magma formation depth of $>40 \mathrm{~km}$. The granitic rocks (ca. 127-124Ma) showed negative Eu anomalies ( $\delta \mathrm{Eu}=0.57-0.96$; average 0.82 ), suggesting the presence of the plagioclase residue and a magma formation depth of $<40 \mathrm{~km}$. In addition, from 128-124 Ma, the depth of the magma source became shallower with continuous extension. Liu et al. [8] considered that the motivation for retreat of the PPO subduction plate was the eastward migration of the deep mantle convection and shallow mantle convection. As the PPO subducted plate retreated, the lithosphere became thinner and the pressure gradually decreased (Figure 13b,c), which contributed to the partial melting of the juvenile crustal rocks [8,35], expressively emerging the Ulanhot intrusive rocks in the central and southern part of the GXR during the Early Cretaceous (Figure 13a) [16,29,35,39,64,83,105,153-155]. 
(a)
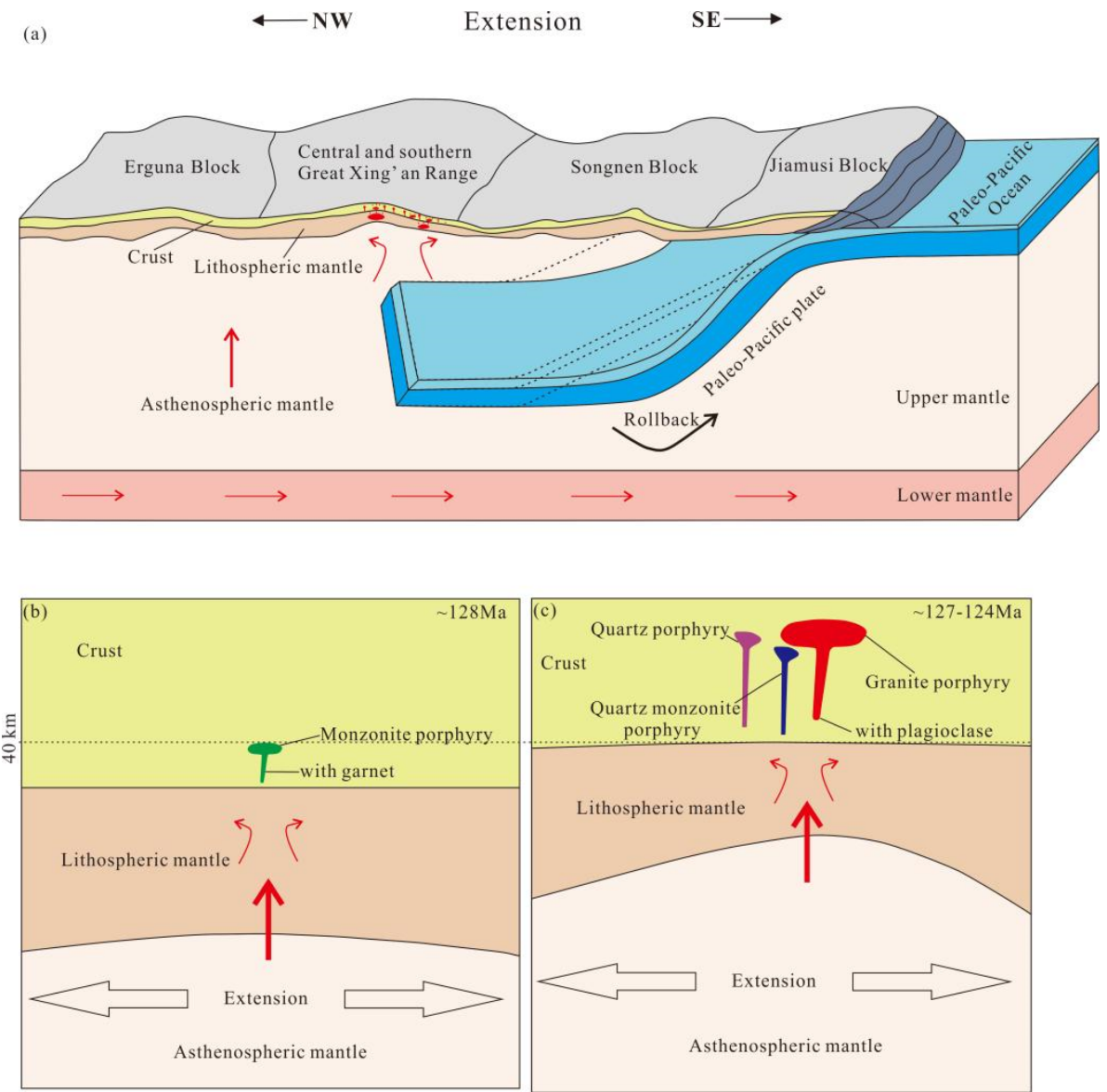

Figure 13. (a) Schematic model for the Early Cretaceous geodynamic processes in the central-southern GXR (modified from Tang et al. [75]); (b) Conceptual model for the formation of the monzonite porphyry (modified from Feng et al. [26]); (c) Conceptual model for the formation of the quartz monzonite porphyry, quartz porphyry, and granite porphyry rocks (modified from Feng et al. [26]).

\section{Conclusions}

LA-ICP-MS zircon U-Pb dating showed that the magmatism in the Ulanhot area (monzonite porphyry: $128.07 \pm 0.62 \mathrm{Ma}$, quartz monzonite porphyry: $127.47 \pm 0.36$, quartz porphyry: $124.85 \pm 0.34$, and granite porphyry: $124.15 \pm 0.31 \mathrm{Ma}$ ) occurred during the Early Cretaceous.

The monzonite porphyry belongs to the metaluminous and alkaline series rocks, which is the product of partial melting of juvenile crustal materials at high pressure. The granitic rocks (e.g., quartz monzonite porphyry, quartz porphyry, and granite porphyry) are I-type granite and belong to the category of high-K calc-alkaline rocks and the primary magmas derived from the partial melting of juvenile crustal rocks, accompanied by strong plagioclase fractional crystallization.

The Early Cretaceous intrusive rocks in the Ulanhot area were formed in an extensional tectonic background and compactly related to the retreat of the PPO subducted plate.

Supplementary Materials: The following are available online at https:/ / www.mdpi.com/article/ $10.3390 / \mathrm{min} 11121414 / \mathrm{s} 1$. Table S1: LA-ICP-MS zircon U-Pb dating results for the intrusive rocks (DBT01, DBT02, XLT01, and SQT01) in the Ulanhot area, Table S2: Major (wt.\%) and trace elements $(\mathrm{ppm})$ results of the intrusive samples from the Ulanhot area, Table S3: Zircon Hf isotopic compositions of the Early Cretaceous Ulanhot intrusive rocks, Table S4: Geochronological data of the Late Mesozoic intrusive rocks in the central-southern Great Xing'an Range. 
Author Contributions: Data treatment and writing original draft, B.T.; review and editing, W.M., G.W., Y.L. and X.K.; supervision and funding acquisition, W.M. All authors have read and agreed to the published version of the manuscript.

Funding: This work was financially supported by the Open Fund of the State Key Laboratory of Oil and Gas Reservoir Geology and Exploitation (Chengdu University of Technology) (PLC20180504), Natural Science Foundation of Inner Mongolia (2021MS04010, 2019LH04002, 2020MS04009) and Inner Mongolia Science and Technology Program (2021GG0251).

Data Availability Statement: Data is available on request from the corresponding author of the manuscript.

Acknowledgments: Special thanks to Liu Changfeng and Chang Zeguang for their valuable help to improve the quality of this paper.

Conflicts of Interest: The authors declare no conflict of interest.

\section{References}

1. Ge, W.C.; Wu, F.Y.; Zhou, C.Y.; Zhang, J.H. Zircon U-Pb ages and its significance of the Mesozoic granites in the Wulanhaote region, central Da Hinggan Mountain. Acta Petrol. Sin. 2005, 21, 749-762. (In Chinese with English Abstract)

2. Wu, F.Y.; Sun, D.Y.; Ge, W.C.; Zhang, Y.B.; Grant, M.L.; Wilde, S.A.; Jahn, B.M. Geochronology of the Phanerozoic granitoids in northeastern China. J. Asian Earth Sci. 2011, 41, 1-30.

3. Guan, Q.B.; Liu, Z.H.; Wang, B.; Wang, X.; Wang, X.A.; Shi, Q.; Chen, Y.S. Middle Jurassic-Early Cretaceous tectonic evolution of the Bayanhushuo area, southern Great Xing'an Range, NE China: Constraints from zircon U-Pb geochronological and geochemical data of volcanic and subvolcanic rocks. Int. Geol. Rev. 2017, 60, 1883-1905. [CrossRef]

4. Zhu, R.X.; Xu, Y.G. The subduction of the west Pacific plate and the destruction of the North China Craton. Sci. China Earth Sci. 2019, 49, 1340-1350. (In Chinese with English Abstract)

5. Li, J.; Wang, K.Y.; Fu, L.J.; Zhang, M.; Liu, H.L.; Liu, Q.Z.; Tang, W.H.; Wang, C.H. Adakitic rocks and A-type felsic dykes in the Changlingzi area, NE China: Constraints on multistage tectonism in the southern Great Xing'an Range. Geol. J. 2019, 55, 5451-5478. [CrossRef]

6. Han, S.J.; Wang, X.; Wang, X.; Wang, Y.; Zhang, Y. Geochronology and geochemistry of late Jurassic-Early Cretaceous volcanic rocks in the southern Great Xing' an range, NE China: Constraints for late Mesozoic tectono-magmatic evolution. Int. Geol. Rev. 2020, 63, 1366-1388. [CrossRef]

7. Guo, X.G.; Li, J.W.; Zhang, D.H.; Xue, F.; Xian, H.B.; Wang, S.J.; Jiao, T.L. Petrogenesis and tectonic setting of igneous rocks from the Dongbulage porphyry Mo deposit, Great Hinggan Range, NE China: Constraints from geology, geochronology, and isotope geochemistry. Ore Geol. Rev. 2020, 120, 1-21.

8. Liu, J.L.; Ni, J.L.; Chen, X.Y.; Craddock, J.P.; Zheng, Y.Y.; Ji, L.; Hou, C.R. Early Cretaceous tectonics across the North Pacific: New insights from multiphase tectonic extension in Eastern Eurasia. Earth-Sci. Rev. 2021, 217, 103552. [CrossRef]

9. Lin, Q.; Ge, W.C.; Sun, D.Y.; Wu, F.Y.; Chong, K.W. Tectonic significance of Mesozoic volcanic rocks in Northeastern China. Sci. Geol. Sin. 1998, 33, 129-139. (In Chinese with English Abstract)

10. Jahn, B.M.; Wu, F.Y.; Chen, B. Massive granitoid generation in central Asia: Nd isotopic evidence and implication for continental growth in the Phanerozoic. Episodes 2000, 23, 82-92.

11. Shao, J.A.; Liu, F.T.; Chen, H.; Han, Q.J. Relationship between Mesozoic magmatism and subduction in Da Hinggan-Yanshan area. Acta Geol. Sin. 2001, 75, 56-63. (In Chinese with English Abstract)

12. Wu, F.Y.; Jahn, B.M.; Wilde, S.A.; Lo, C.H.; Yui, T.F.; Lin, Q.; Ge, W.-C.; Sun, D.Y. Highly fractionated I-type granites in NE China (I): Geochronology and petrogenesis. Lithos 2003, 66, 241-273. [CrossRef]

13. Wu, F.Y.; Jahn, B.M.; Wilde, S.A.; Lo, C.H.; Yui, T.F.; Lin, Q.; Ge, W.-C.; Sun, D.Y. Highly fractionated I-type granites in NE China (II): Isotopic geochemistry and implications for crustal growth in the Phanerozoic. Lithos 2003, 67, 191-204. [CrossRef]

14. Zhang, C.; Yang, W.H.; He, Z.H.; Wu, H.; Wu, Q. Chronology and geochemistry of rhyolites in Manketou'ebo Formation from Ta'erqi area, southern-central Greater Xing'an Range. Glob. Geol. 2014, 33, 255-256. (In Chinese with English Abstract)

15. Wang, T.; Guo, L.; Zhang, L.; Yang, Q.D.; Zhang, J.J.; Tong, Y.; Ye, K. Timing and evolution of Jurassic-Cretaceous granitoid magmatisms in the Mongol-Okhotsk belt and adjacent areas, NE Asia: Implications for transition from contractional crustal thickening to extensional thinning and geodynamic settings. J. Asian Earth Sci. 2015, 97, 365-392.

16. Liu, C.F.; Zhou, Z.G.; Tang, Y.J.; Wu, C.; Li, H.Y.; Zhu, Y.; Jiang, T.; Liu, W.; Ye, B.Y. Geochronology and tectonic settings of Late Jurassic-Early Cretaceous intrusive rocks in the Ulanhot region, central and southern Da Xingan Range. Geol. Mag. 2016, 154, 923-945. [CrossRef]

17. Liu, C.F.; Zhou, Z.G.; Wang, G.S.; Wu, C.; Li, H.Y.; Zhu, Y.; Jiang, T.; Liu, W.; Ye, B.Y. Geochronology and geochemistry of the Late Jurassic bimodal volcanic rocks from Hailisen area, central-southern Great Xing'an Range, Northeast China. Geol. J. 2017, 53, 2099-2117.

18. Wei, W.; Zou, T.; Huang, X.; Jiang, B.; Zhu, X.; Wu, X. Petrogenesis of early Cretaceous granitoids in the southern Great Xing'an Range, NE China: Constraints from the Haliheiba pluton. Geochemistry 2020, 80, 125608. [CrossRef] 
19. Li, M.X. Geochemical characteristics and petrogenesis of Early Cretaceous monzonitic granite in theMandu area, southern Da Hinggan Mountains. Geol. Bull. China 2020, 39, 224-233.

20. Gao, S.; Chen, W.F.; Ling, H.F.; Sun, L.Q.; Ren, Q.; Xie, G.A.; Wang, K.X.; Tian, R.S. A latest Jurassic A-type granite in the Middle of Inner Mongolia: Petrogenesis and tectonic implications. Lithos 2021, 394-395, 106167. [CrossRef]

21. Sengör, A.M.C.; Natal'in, B.A.; Burtman, V.S. Evolution of the Altaid tectonic collage and Palaeozoic crustal growth in Eurasia. Nature 1993, 364, 299-307. [CrossRef]

22. Zhao, Y.M.; Zhang, D.Q. Metallogeny and Prospective Evaluation of Copperpolymetallic Deposits in the Da Hinggan Mountains and Its Adjacent Regions; Seismological Press: Beijing, China, 1997; pp. 1-318. (In Chinese)

23. Zhou, Y.; Ge, W.C.; Wang, Q.H. Petrogenesis of Mesozoic granite in Wulanhaote region, central Da Hinggan Mountains: Constraints from geochemistry and Sr-Nd-Hf isotope. Acta Petrol. Mineral. 2011, 30, 901-923. (In Chinese with English Abstract)

24. Zhou, Z.H.; Mao, J.W.; Liu, J.; Ouyang, H.G.; Che, H.W.; Ma, X.H. Early Cretaceous magmatism and ore mineralization in Northeast China: Examples from Taolaituo Mo and Aobaotu Pb-Zn deposits. Int. Geol. Rev. 2015, 57, 229-256. [CrossRef]

25. Cui, F.H.; Xu, X.C.; Zheng, C.Q.; Yao, W.G.; Shi, L. The Paleo-Pacific plate subduction and slab roll-back beneath eastern North China Craton: Insights from the Late Mesozoic granitoids in Xingcheng area, western Liaoning Province. Acta Petrol. Sin. 2020, 36, 2463-2492. (In Chinese with English Abstract)

26. Feng, Y.Z.; Chen, H.Y.; Xiao, B.; Li, R.C.; Deng, C.Z.; Han, J.S.; Li, G.H.; Shi, H.L.; Lai, C.K. Late Mesozoic magmatism at Xiaokelehe $\mathrm{Cu}-\mathrm{Mo}$ deposit in Great Xing'an Range, NE China: Geodynamic and metallogenic implications. Lithos 2020, 374, 105713. [CrossRef]

27. Mi, K.F.; Lü, Z.C.; Zhao, S.J.; Yan, T.J.; Yu, H.Y.; Dong, S.Y. Petrogenesis and metallogenic implications of the Late Jurassic Dagayin pluton, southern Great Xing'an Range, northeast China: Integrated geochronological, petrological, and geochemical constraints. J. Geochem. Explor. 2020, 220, 106666. [CrossRef]

28. Mao, J.W.; Zhang, Z.H.; Yu, J.J.; Niu, B.G. Geodynamic settings of Mesozoic large-scale mineralisation in North China and adjacent areas-implication from the highly precise dating of ore deposits. Sci. China Ser. D Earth Sci. 2003, 46, 838-851.

29. Zheng, Y.F.; Wu, F.Y. Growth and reworking of cratonic lithosphere. Chin. Sci. Bull. 2009, 54, 1945-1949. (In Chinese with English Abstract) [CrossRef]

30. Ying, J.F.; Zhou, X.H.; Zhang, L.C.; Wang, F. Geochronological framework of Mesozoic volcanic rocks in the Great Xing'an Range, NE China, and their geodynamic implications. J. Asian Earth Sci. 2010, 39, 786-793. [CrossRef]

31. Guo, F.; Fan, W.M.; Gao, X.F.; Li, C.W.; Miao, L.C.; Zhao, L.A.; Li, H.X. Sr-Nd-Pb isotope mapping of Mesozoic igneous rocks in NE China constraints on tectonic framework and Phanerozoic crustal growth. Lithos 2010, 120, 563-578. [CrossRef]

32. Wu, C.; Jiang, T.; Liu, W.C.; Zhang, D.; Zhou, Z.G. Early Cretaceous adakitic granites and mineralization of the Yili porphyry Mo deposit in the Great Xing'an Range: Implications for the geodynamic evolution of northeastern China. Int. Geol. Rev. 2014, 57, 1152-1171. [CrossRef]

33. Yang, Y.T.; Guo, Z.X.; Song, C.C.; He, S. A short-lived but significant Mongol-Okhotsk collisional orogeny in latest Jurassic-earliest Cretaceous. Gondwana Res. 2015, 28, 1096-1116. [CrossRef]

34. Liu, H.N.; Yuan, F.; Zhao, S.J.; Fan, M.J.; Guo, X.G. SHRIMP U-Pb Zircon Ages, Geochemistry and Sr-Nd-Hf Isotope Systematics of the Zalute Intrusive Suite in the Southern Great Xing'an Range, NE China: Petrogenesis and Geodynamical Implications. Minerals 2020, 10, 927. [CrossRef]

35. Jing, J.H.; Yang, H.; Ge, W.C.; Dong, Y.; Ji, Z.; Jing, Y.; Bi, J.H.; Zhou, H.Y. Early Cretaceous crust-mantle interaction linked to rollback of the Palaeo-Pacific flat-subducting slab: Constraints from the intermediate-felsic volcanic rocks of the northern Great Xing'an Range, NE China. Geol. Mag. 2021, 158, 1617-1638. [CrossRef]

36. Maruyama, S. Pacific-type orogeny revisited: Miyashiro-type orogeny proposed. Isl. Arc 1997, 6, 91-120. [CrossRef]

37. Dong, Y.; Ge, W.C.; Yang, H.; Zhao, G.C.; Wang, Q.H.; Zhang, Y.L.; Su, L. Geochronology and geochemistry of Early Cretaceous volcanic rocks from the Baiyingaolao Formation in the central Great Xing'an Range, NE China, and its tectonic implications. Lithos 2014, 205, 168-184. [CrossRef]

38. Li, S.; Chung, S.L.; Wang, T.; Wilde, S.A.; Chu, M.F.; Guo, Q.Q. Tectonic significance and geodynamic processes of large-scale Early Cretaceous granitoid magmatic events in the southern Great Xing'an Range, North China. Tectonics 2017, 36, 615-633. [CrossRef]

39. Pang, Y.M.; Guo, X.W.; Zhang, X.H.; Zhu, X.P.; Hou, F.H.; Wen, Z.H.; Han, Z.Z. Late Mesozoic and Cenozoic tectono-thermal history and geodynamic implications of the Great Xing'an Range, NE China. J. Asian Earth Sci. 2019, 189, 104155. [CrossRef]

40. Ge, W.C.; Lin, Q.; Sun, D.Y.; Wu, F.Y.; Won, C.K.; Lee, M.W.; Yun, S.H. Geochemical characteristics of the Mesozoic basalts in Da Hinggan Ling: Evidence of the mantle-crust interaction. Acta Petrol. Sin. 1999, 15, 397-407.

41. Xiao, W.J.; Windley, B.F.; Hao, J.; Zhai, M.G. Accretion leading to collision and the Permian Solonker suture, Inner Mongolia, China: Termination of the central Asian orogenic belt. Tectonics 2003, 22, 8-20. [CrossRef]

42. Tang, J.; Xu, W.L.; Wang, F.; Wang, W.; Xu, M.J.; Zhang, Y.H. Geochronology and geochemistry of Early-Middle Triassic magmatism in the Erguna Massif, NE China: Constraints on the tectonic evolution of the Mongol-Okhotsk Ocean. Lithos 2014, 184, 1-16. [CrossRef]

43. Han, X.M.; Zheng, C.Q.; Han, Y.B.; Xu, X.C.; Shi, L.; Xu, J.L.; Li, J. Detrital zircon U-Pb ages of the Murui Formation in the Zhalantun area: Implications for the Early Cretaceous tectonic setting of the southern Great Xing'an Range, NE China. Geol. J. 2017, 53, 2874-2895. [CrossRef] 
44. Deng, C.Z.; Sun, D.Y.; Han, J.S.; Chen, H.Y.; Li, G.H.; Xiao, B.; Li, R.C.; Feng, Y.Z.; Li, C.L.; Lu, S. Late-stage southwards subduction of the Mongol-Okhotsk oceanic slab and implications for porphyry $\mathrm{Cu}-\mathrm{Mo}$ mineralization: Constraints from igneous rocks associated with the Fukeshan deposit, NE China. Lithos 2019, 326, 341-357. [CrossRef]

45. Tang, J.; Xu, W.L.; Wang, F.; Ge, W.C. Subduction history of the Paleo-Pacific slab beneath Eurasian continent: Mesozoic-Paleogene magmatic records in Northeast Asia. Sci. China Earth Sci. 2018, 61, 527-559. (In Chinese with English Abstract) [CrossRef]

46. Yarmolyuk, V.V.; Kovalenko, V.I.; Ivanov, V.G. The Late Mezosoic-Cenozoic Interplate Volcanic Province in Central East Asia: A projection of mantle hot field. Geotectonics 1995, 5, 41-67.

47. Fan, W.M.; Guo, F.; Wang, Y.J.; Lin, G. Late Mesozoic calc-alkaline volcanism of post-orogenic extension in the northern Da Hinggan Mountains, Northeastern China. J. Volcanol. Geotherm. Res. 2003, 121, 115-135. [CrossRef]

48. Gou, J.; Sun, D.Y.; Qin, Z. Late Jurassic-Early Cretaceous tectonic evolution of the Great Xing'an range: Geochronological and geochemical evidence from granitoids and volcanic rocks in the Erguna Block, NE China. Int. Geol. Rev. 2019, 61, 1842-1863. [CrossRef]

49. Donskaya, T.V.; Gladkochub, D.P.; Mazukabzov, A.M.; Ivanov, A.V. Late Paleozoic-Mesozoic subduction-related magmatism at the southern margin of the Siberian continent and the 150 million year history of the Mongol-Okhotsk Ocean. J. Asian Earth Sci. 2013, 62, 79-97. [CrossRef]

50. Wang, T.; Zheng, Y.D.; Zhang, J.J.; Zeng, L.S.; Donskaya, T.; Guo, L.; Li, J.B. Pattern and kinematic polarity of Late Mesozoic extension in continental NE Asia: Perspectives from metamorphic core complexes. Tectonics 2011, 30, TC6007. [CrossRef]

51. Shao, J.A.; Zhang, L.Q.; Jia, W.; Wang, P.Y. Harkin metamorphic core complex in Inner Mongolia and its upwelling mechanism. Acta Petrol. Sin. 2001, 17, 283-290. (In Chinese with English Abstract)

52. Zhang, L.Q.; Shao, J.A.; Zheng, G.R. Metamorphic core complex in Ganzhuermiao, Inner Mongolia. Sci. Geol. Sin. 1998, 33, 14-20. (In Chinese with English Abstract)

53. Wu, F.Y.; Lin, J.Q.; Wilde, S.A.; Zhang, X.O.; Yang, J.H. Nature and significance of the Early Cretaceous giant igneous event in eastern China. Earth Planet. Sci. Lett. 2005, 233, 103-119. [CrossRef]

54. Shu, Q.; Chang, Z.; Lai, Y.; Zhou, Y.; Sun, Y.; Yan, C. Regional metallogeny of Mobearing deposits in northeastern China, with new Re-Os dates of porphyry Mo deposits in the northern Xilamulun district. Econ. Geol. 2016, 111, 1783-1798. [CrossRef]

55. Yang, X.P. Jiang, B.; Yang, Y.J. Spatial-Temporal Distribution Characteristics of Early Cretaceous Volcanic Rocks in Great Xing'an Range Area. Earth Sci. 2019, 44, 3237-3251.

56. Zhang, J.H.; Gao, S.; Ge, W.C.; Wu, F.Y.; Yang, J.H.; Wilde, S.A.; Li, M. Geochronology of the Mesozoic volcanic rocks in the great Xing'an range, northeastern China: Implications for subduction-induced delamination. Chem. Geol. 2010, 276, 144-165. [CrossRef]

57. Ji, Z.; Wan, C.B.; Meng, Q.A.; Zhu, D.F.; Ge, W.C.; Zhang, L.Y.; Yang, H.; Dong, Y.; Jing, Y. Chronostratigraphic framework of late Mesozoic terrestrial strata in the Hailar-Tamtsag Basin, Northeast China, and its geodynamic implication. Geol. J. 2019, 55, 5197-5215. [CrossRef]

58. Ji, Z.; Meng, Q.A.; Wan, C.B.; Ge, W.C.; Yang, H.; Zhang, Y.L.; Dong, Y.; Jin, X. Early Cretaceous adakitic lavas and A-type rhyolites in the Songliao Basin, NE China: Implications for the mechanism of lithospheric extension. Gondwana Res. 2019, 71, 28-48. [CrossRef]

59. Ji, Z.; Meng, Q.A.; Wan, C.B.; Zhu, D.F.; Ge, W.C.; Zhang, Y.L.; Yang, H.; Dong, Y. Geodynamic evolution of flat-slab subduction of Paleo-Pacific Plate: Constraints from Jurassic adakitic lavas in the Hailar Basin, NE China. Tectonics 2019, 38, 4301-4319. [CrossRef]

60. Zhu, R.X.; Fan, H.R.; Li, J.W.; Meng, Q.R.; Li, S.R.; Zeng, Q.D. Decratonic gold deposits. Sci. China Earth Sci. 2015, 45, 1523-1537. (In Chinese with English Abstract) [CrossRef]

61. Suo, Y.H.; Li, S.Z.; Cao, X.Z.; Li, X.Y.; Liu, X.; Cao, H.H. Mesozoic-Cenozoic inversion tectonics of East China and its implications for the subduction process of the oceanic Plate. Earth Sci. Front. 2017, 24, 249-267. (In Chinese with English Abstract)

62. Tian, Y.; Ma, J.C.; Liu, C.; Feng, X.; Liu, T.T.; Zhu, H.X.; Yan, D.; Li, H.H. Effects of subduction of the western Pacific plate on tectonic evolution of Northeast China and geodynamic implications. Chin. J. Geophys. 2019, 62, 1071-1082. (In Chinese with English Abstract)

63. Zhang, C.; Quan, J.Y.; Zhang, Y.J.; Liu, Z.H.; Li, W.; Wang, Y.; Qian, C.; Zhang, L.; Ge, J.T. Late Mesozoic tectonic evolution of the southern Great Xing'an Range, NE China: Evidence from whole-rock geochemistry, and zircon U-Pb ages and Hf isotopes from volcanic rocks. Lithos 2020, 61, 1-27. [CrossRef]

64. Lu, K.J.; He, Z.H.; Duo, Z.M.; Gao, L.F.; Liu, F.Y. Geochronology, petrogenesis and tectonic setting of monzogranite from Wulanhaote area, Inner Mongolia. Glob. Geol. 2018, 37, 56-69. (In Chinese with English Abstract)

65. Wang, L.; Tang, L.; Zhang, S.T.; Stantosh, M.; Pei, Q.M.; Gao, H.W.; Liu, F.G. Genesis of the Yujiadian F-Pb-Zn-Ag deposit, Inner Mongolia, NE China: Constraints from geochemistry, fluid inclusion, zircon geochronology and stable isotopes. Ore Geol. Rev. 2020, 122, 103528. [CrossRef]

66. Keevil, H.A.; Monecke, T.; Goldfarb, R.J.; Möller, A.; Kelly, N.M. Geochronology and geochemistry of Mesozoic igneous rocks of the Hunjiang basin, Jilin Province, NE China: Constraints on regional tectonic processes and lithospheric delamination of the eastern North China block. Gondwana Res. 2018, 68, 127-157. [CrossRef]

67. Wu, F.Y.; Li, X.H.; Yang, J.H.; Zheng, Y.F. Discussions on the petrogenesis of granites. Acta Petrol. Sin. 2007, 23, 1217-1238. (In Chinese with English Abstract) 
68. Xu, G.Z.; Deng, C.Z.; Li, C.L.; Lv, C.L.; Yin, R.S.; Ding, J.S.; Yuan, M.W.; Gou, J. Petrogenesis of Late Carboniferous A-type granites and Early Cretaceous adakites of the Songnen Block, NE China: Implications for the geodynamic evolution of the Paleo-Asian and Paleo-Pacific oceans. Lithos 2020, 366, 105575. [CrossRef]

69. Jia, D.C.; Hu, R.Z.; Lu, Y.; Qiu, X.L. Collision belt between the Khanka block and the North China block in the Yanbian Region. Northeast. China J. Asian Earth Sci. 2004, 23, 211-219.

70. Eizenhöfer, P.R.; Zhao, G.C.; Sun, M.; Zhang, J.; Han, Y.G.; Hou, W.Z. Geochronological and Hf isotopic variability of detrital zircons in Palaeozoic sedimentary strata across the accretionary collision zone between the North China Craton and the Mongolian arcs, and its tectonic implications. Geol. Soc. Am. Bull. 2015, 127, 1422-1436. [CrossRef]

71. Zhu, P.P.; Cheng, Q.M.; Zhang, Z.J.; Wang, Z.Y. Genesis and implications of the Late Jurassic Hailesitai granites in the northern Greater Khingan Range: Evidence from zircon U-Pb dating and Hf isotope. Geol. Mag. 2016, 154, 963-982. [CrossRef]

72. Xu, W.L.; Pei, F.P.; Wang, F.; Meng, E.; Ji, W.Q.; Yang, D.B.; Wang, W. Spatial-temporal relationships of Mesozoic volcanic rocks in NE China: Constraints on tectonic overprinting and transformations between multiple tectonic regimes. J. Asian Earth Sci. 2013, 74, 167-193. [CrossRef]

73. Dai, M.; Yan, G.S.; Liu, C.; Deng, J.F.; Li, Y.S.; Jia, W.B.; Lai, C.K. Southward subduction of the Mongolia-Okhostk Ocean: Insights from Early-Middle Triassic intrusive rocks from the Jiawula-Tsagenbulagen area in NE China. Geol. J. 2018, 55, 967-993. [CrossRef]

74. Şengör, A.M.C.; Natal'in, B.A. Paleotectonics of Asia: Fragments of a synthesis. In The Tectonic Evolution of Asia; Yin, A., Harrison, T.M., Eds.; Cambridge University Press: New York, NY, USA, 1996; pp. 486-640.

75. Tang, Z.Y.; Sun, D.Y.; Mao, A.Q.; Ynag, D.G. Timing and evolution of Mesozoic volcanism in the central Great Xing'an Range, northeastern China. Geol. J. 2018, 54, 3737-3754. [CrossRef]

76. Wan, L.; Lu, C.D.; Zeng, Z.X.; Adil, S.M.; Liu, Z.H.; Dai, Q.Q.; Chen, K.L. Nature and significance of the late Mesozoic granitoids in the southern Great Xing'an range, eastern Central Asian Orogenic Belt. Int. Geol. Rev. 2019, 61, 584-606. [CrossRef]

77. Zhou, Z.G.; Liu, C.F.; Wang, G.S.; Zhang, N.; Li, H.Y.; Wu, C. Geochronology, geochemistry and tectonic significance of the Dashizhai ophiolitic mélange belt, southeastern Xing'an-Mongolia orogenic belt. Int. J. Earth Sci. 2018, 108, 67-88. [CrossRef]

78. Li, Z.H.; Cheng, Z.X.; Li, K.; Wang, L.J. Geochronological and geochemical characteristics of Late Early Cretaceous granitic porphyry in the Ulanhot area and its tectonic setting. East China Geol. 2020, 41, 229-236.

79. Bureau of Geology and Mineral Resources of Nei Mongol Autonomous Region (BGMRN). Regional Geology of Inner Mongolia Autonomous Region (1:200,000 Wulanhaote Region); China University of Geosciences Publishing House: Hubei, China, 1965. (In Chinese)

80. Han, G.Q.; Liu, Y.J.; Neubauer, F.; Genser, J.; Liang, C.Y.; Wen, Q.B.; Zhao, Y.L. Chronology of L-Type tectonite from Nierji area in the northern-middle segment of the western boundary fault of the Songliao Basin and its tectonic implications. Acta Petrol. Sin. 2014, 30, 1922-1934.

81. Wang, D.X.; He, H.Y.; Zhao, L.; Gu, X.Y.; Zhang, H.P.; Hao, R.C. The response of Early Cretaceous ductile deformation to the Nen-jiang-Balihan fault in Ulanhot area, Inner Mongolia. Geol. Bull. China (In Chinese with English Abstract). 2018, 37, 1704-1709.

82. Gu, A.L.; Sun, J.G.; Bai, L.A.; Zhao, K.Q.; Wang, Z.Y. Study on Metallogenic Mechanism about Epithermal Copper Deposits of Naoniu Mountain in the Central and East of the Great Xing'an Range: Which from the Constraints Related to Geochemistry and Chronology. J. Jilin Univ. 2015, 45, 1548. (In Chinese with English Abstract)

83. Wang, Y.L.; Ao, G.; Wang, H.P.; Wang, Z.J.; Wang, Q.; Ke, K.J. Zircon U-Pb Geochronology, Geochemistry and Tectonic Significance of Early Cretaceous Granites in Suolun Area of Central Da Hinggan Mountains. Geol. Sci. Technol. Inf. 2019, 38, 45-57. (In Chinese with English Abstract)

84. Andersen, T. Correction of common lead in U-Pb analyses that do not report ${ }^{204} \mathrm{~Pb}$. Chem. Geol. 2002, 192, 59-79. [CrossRef]

85. Ludwig, K.R. ISOPLOT 3.00: A geochronological toolkit for Microsoft Excel. Calif. Berkeley Geochronol. Cent. Berkeley $2003,4,70$.

86. Hu, Z.; Liu, Y.; Gao, S.; Liu, W.; Zhang, W.; Tong, X.; Lin, L.; Zong, K.; Li, M.; Chen, H.; et al. Improved in situ Hf isotope ratio analysis of zircon using newly designed $X$ skimmer cone and jet sample cone in combination with the addition of nitrogen by laser ablation multiple collector ICP-MS. J. Anal. At. Spectrom. 2012, 27, 1391-1399. [CrossRef]

87. Sláma, J.; Košler, J.; Condon, D.J.; Crowley, J.L.; Gerdes, A.; Hanchar, J.M.; Horstwood, M.S.A.; Whitehouse, M.J. Plešovice zircon-A new natural reference material for U-Pb and Hf isotopic microanalysis. Chem. Geol. 2008, 249, 1-35. [CrossRef]

88. Lu, Y.F. Geokit-A geochemical toolkit for Microsoft Excel. Geochimica 2004, 33, 459-464. (In Chinese with English Abstract)

89. Lu, Y.F.; Li, W.X. Calculation and Program Design for Pb-Sr-Nd-Hf Isotopic Parameters. South China Geol. 2021, 37, 233-245. (In Chinese with English Abstract)

90. Söderlund, U.; Patchett, P.J.; Vervoort, J.D.; Isachsen, C.E. The ${ }^{176} \mathrm{Lu}$ Decay Constant Determined by Lu-Hf and U-Pb Isotope Systematics of Precambrian Mafic Intrusions. Earth Planet. Sci. Lett. 2004, 219, 311-324. [CrossRef]

91. Wu, F.Y.; Li, H.X.; Zheng, Y.F.; Gao, S. Lu-Hf isotopic systematics and their applications in petrology. Acta Petrol. Sin. 2007, 23, 185-220. (In Chinese with English Abstract)

92. Blichert-Toft, J.; Albarède, F. The Lu-Hf geochemistry of chondrites and the evolution of the mantle-crust system. Earth Planet. Sci. Lett. 1997, 148, 243-258. [CrossRef]

93. Griffin, W.L.; Pearson, N.J.; Belousova, E.; Jackson, S.E.; Van, A.E.; O’Reilly, S.Y.; Shee, S.R. The Hf isotope composition of cratonic mantle: LAM-MCICPMS analysis of zircon megacrysts in kimberlites. Geochim. Cosmochim. Acta 2000, 64, 133-147. [CrossRef] 
94. GERM. Geochemical Earth Reference Model. 2001. Available online: http:/ / earthref.org/GERM/ (accessed on 1 December 2021).

95. Griffin, W.L.; Wang, X.; Jackson, S.E.; Pearson, N.J.; O’Reilly, S.Y.; Xu, X.S.; Zhou, X.M. Zircon Chemistry and Magma Mixing, SE China: In-situ Analysis of Hf Isotopes, Tonglu and Pingtan Igneous Complexes. Lithos 2002, 61, 237-269. [CrossRef]

96. Gao, S.; Rudnick, R.L.; Xu, W.L.; Yuan, H.L.; Liu, Y.S.; Walker, R.J.; Puchtel, I.S.; Liu, X.; Huang, H.; Wang, X.-R.; et al. Recycling deep cratonic lithosphere and generation of intraplate magmatism in the North China Craton. Earth Planet. Sci. Lett. 2008, 270, 41-53. [CrossRef]

97. Koschek, G. Origin and significance of the SEM cathodoluminescence from zircon. J. Microsc. 1993, 171, 223-232. [CrossRef]

98. Middlemost, E.A.K. Magmas and Magmatic Rocks: An Introduction to Igneous Petrology; Longman Group: London, UK, 1985; pp. 73-87.

99. Irvine, T.H.; Baragar, W.R.A. A guide to the chemical classification of the common volcanic rocks. Can. J. Earth Sci. 1971, 8, 523-548. [CrossRef]

100. Peccerillo, A.; Taylor, S.R. Geochemistry of Eocene calc-alkaline volcanic rocks from the Kastamonu area, northern Turkey. Contrib. Mineral. Petrol. 1976, 58, 63-81. [CrossRef]

101. Maniar, P.D.; Piccoli, P.M. Tectonic discrimination of granitoids. Geol. Soc. Am. Bull. 1989, 101, 635-643. [CrossRef]

102. Boynton, W.V. Geochemistry of the rare earth elements: Meteorite studies. In Rare Earth Element Geochemistry; Henderson, P., Ed.; Elsevier: Amsterdam, The Netherlands, 1984; pp. 63-114.

103. Sun, S.S.; McDonough, W.F. Chemical and isotopic systematics of oceanic basalts: Implications for mantle composition and processes. Geol. Soc. 1989, 42, 313-345. [CrossRef]

104. Yang, J.H.; Wu, F.Y.; Shao, J.A.; Wilde, S.A.; Xie, L.W.; Liu, X.M. Constraints on the timing of uplift of the Yanshan Fold and Thrust Belt. North China Earth Planet. Sci. Lett. 2006, 246, 336-352. [CrossRef]

105. Gao, F.; Liu, Y.J.; Wen, Q.B.; Li, W.M.; Feng, Z.Q.; Fan, W.L.; Tang, C. Zircon U-Pb Ages and Its Geological Implication of Mesozoic Granites in Tuquan-Keerqin Youyizhongqi Region. J. Jilin Univ. 2018, 48, 769-783. (In Chinese with English Abstract)

106. Chen, L.L.; Cheng, Z.G. Petrology and zircon chronology of the Dorolj granite in Hinggan League, Inner Mongolia. Geol. China 2015, 42, 891-908. (In Chinese with English Abstract)

107. Song, W.M.; Pang, X.J.; Fu, J.Y.; Tao, N.; Yang, J.L.; Du, J.Y.; Wu, T. Zircon U-Pb Geochronology, Geochemistry and Dynamics of the Alkali Feldspar Granite in Horqin Right Wing Middle Banner of Inner Mongolia, with Implications for the Geodynamic Setting. J. Jilin Univ. 2015, 45, 847-859. (In Chinese with English Abstract)

108. Wu, G.; Liu, R.L.; Chen, G.Z.; Li, T.G.; Li, R.H.; Li, Y.L.; Yang, F.; Zhang, T. Mineralization of the Weilasituo rare metaltinpolymetallic ore deposit in Inner Mongolia: Insights from fractional crystallization of granitic magmas. Acta Petrol. Sin. 2021, 37, 637-664.

109. Wang, X.L.; Liu, J.J.; Zhai, D.G.; Yang, Y.Q.; Wang, J.P.; Zhang, Q.B.; Zhang, A.L. U-Pb, Geochemistry and Tectonic Implications of Bianjiadayuan Quartz Porphyry, Inner Mongolia, China. Bull. Mineral. Petrol. Geochem. 2014, 33, $654-665$.

110. Feeley, T.C.; Hacker, M.D. Intracrustal derivation of Na-rich andesite and dacite magmas: An example from Volcan Ollagüe. Andean Central Volcanic Zone. J. Geol. 1995, 103, 213-225. [CrossRef]

111. Yang, J.H.; Chung, S.L.; Wilde, S.A.; Wu, F.Y.; Chu, M.F.; Lo, C.H.; Fan, H.R. Petrogenesis of post-orogenic syenites in the Sulu Orogenic Belt, East China: Geochronological, geochemical and Nd-Sr isotopic evidence. Chem. Geol. 2005, 214, 99-125. [CrossRef]

112. Thompson, A.B. Fertility of crustal rocks during Anatexis. Earth Environ. Sci. Trans. R. Soc. Edinb. 1996, 87, 1-10.

113. King, P.L.; White, A.J.R.; Chappell, W.; Allen, C.M. Characterization and origin of aluminous A-type granites from the Lachlan Fold Belt. Southeast. Aust. J. Petrol. 1997, 38, 371-391.

114. Litvinovsky, B.A.; Iahn, B.M.; Zanvilevich, A.N.; Sounders, A.; Poulein, S.; Kuzmin, D.V.; Reichow, M.K.; Titov, A.V. Petrogenesis of syenite granite suites from the Bryansky Complex (Transbaikalia Russia): Implications for the origin of A-type granitoid magmas. Chem. Geol. 2002, 189, 105-133. [CrossRef]

115. Frey, F.A.; Green, D.H. Integrated models of basalt petrogenesis: A study of quartz tholeiites to olivine melilitites from South Eastern Australia utilising geochemical and experimental petrological data. J. Pet. 1978, 19, 463-513. [CrossRef]

116. Grove, T.L.; Elkins-tanton, L.T.; Parman, S.W. Fractional crystallization and mantle-melting controls on calc-alkaline differentiation trends. Contrib. Mineral. Petrol. 2003, 145, 515-533. [CrossRef]

117. Dong, X.; Niu, Y.; Zhang, Z.; Tian, Z.; He, Z. Mesozoic crustal evolution of southern Tibet: Constraints from the early Jurassic igneous rocks in the Central Lhasa terrane. Lithos 2020, 366-367, 105557. [CrossRef]

118. Mckenizie, D.P. Some remarks on the movement of small melt fractions in the mantle. Earth Planet. Sci. Lett. 1989, 95, 53-72. [CrossRef]

119. Peacock, S.M. Fluid processes in subduction zones. Science 1990, 248, 329-337. [CrossRef] [PubMed]

120. Hofmann, A.W.; Jochum, K.P.; Seufert, M.; White, W.M. Nb and Pb in oceanic basalts: New constraints on mantle evolution. Earth Planet. Sci. Lett. 1986, 79, 33-45. [CrossRef]

121. Kelemen, P.B.; Rilling, J.L.; Parmentier, E.M.; Mehl, L.; Hacker, B.R. Thermal structure due to solid-state flow in the Mantle wedge beneath arcs. In Inside the Subduction Factory; Eiler, J., Ed.; American Geophysical Union Geophysical Monograph: Washington, DC, USA, 2003; Volume 138, pp. 293-311.

122. Rapp, R.P.; Watson, E.B. Dehydration Melting of Metabasalt at $8 \sim 32$ Kbar: Implications for Continental Growth and Crust-Mantle Recycling. J. Petrol. 1995, 36, 891-931. [CrossRef]

123. Castillo, P.R. An overview of adakite petrogenesis. Chin. Sci. Bull. 2006, 51, 257-268. [CrossRef] 
124. Green, T.H. Anatexis of Mafic Crust and High Pressure Crystallization of Andesites, Andesites-Orogenic Andesites and Related Rocks; Thorpe, R.S., Ed.; John Wiley and Sons: Hoboken, NJ, USA, 1982; pp. 465-487.

125. Chappell, B.W.; White, A.J.R. Two contrasting granite type. Pac. Geol. 1974, 8, 173-174.

126. Collins, W.J.; Beams, S.D.; White, A.J.R.; Chappell, B.W. Nature and origin of Atype granites with particular reference to southeastern Australia. Contrib. Mineral. Petrol. 1982, 80, 189-200. [CrossRef]

127. Wyllie, P.J. Crustal anatexis: An experimental review. Tectonophysics 1977, 43, 41-71. [CrossRef]

128. Whalen, J.B.; Currie, K.L.; Chappell, B.W. A-type granites: Geochemical characteristics, discrimination and petrogenesis. Contrib. Mineral. Petrol. 1987, 95, 407-419. [CrossRef]

129. Chappell, B.W.; White, A.J.R. I- and S- type granites in the Lachlan Fold Belt. Trans. R. Soc. Edinb. Earth Sci. 1992, 83, 1-26.

130. Clemens, J.D. S-type granitic magamas-petrogenetic issues: Models and evidence. Earth Sci. Rev. 2003, 61, 1-18. [CrossRef]

131. Harrison, T.M.; Watson, E.B. The behavior of apatite during crustal anatexis: Equilibrium and kinetic considerations. Geochim. Cosmochim. Acta 1984, 48, 1467-1477. [CrossRef]

132. Chappell, B.W. Aluminium saturation in I- and S-type granites and the characterization of fractionated haplogranites. Lithos 1999, 46, 535-551. [CrossRef]

133. King, P.L.; Chappell, B.W.; Allen, C.M.; White, A.J.R. Are A-type granites the high temperature felsic granites? Evidence from fractionated granites of the Wangrah Suite. Aust. J. Earth Sci. 2001, 48, 501-514. [CrossRef]

134. Watson, E.B.; Harrison, T.M. Zircon saturation revisited: Temperature and composition effects in a variety of crustal magma types. Earth Planet. Sci. Lett. 1983, 64, 295-304. [CrossRef]

135. Chappell, B.W.; White, A.J.R.; Williams, I.S.; Wyborn, D. Low-and high-temperature granites. Trans. R. Soc. Edinb. Earth Sci. 2004, 95, 125-140.

136. Karsli, O.; Dokuz, A.; Uysal, I.; Aydin, F.; Kandemir, R.; Wijbrans, J. Generation of the Early Cenozoic adakitic volcanism by partial melting of mafic lower crust, Eastern Turkey: Implications for crustal thickening to delamination. Lithos 2010, 114, 109-120. [CrossRef]

137. Wyborn, D.; Chappell, B.W.; James, M. Examples of convective fractionation in high-temperature granites from the Lachlan Fold Belt. Aust. J. Earth Sci. 2001, 48, 531-541. [CrossRef]

138. Ouyang, H.G.; Mao, J.W.; Zhou, Z.H.; Su, H.M. Late Mesozoic metallogeny and intracontinental magmatism, southern Great Xing'an Range, northeastern China. Gondwana Res. 2015, 27, 1153-1172. [CrossRef]

139. Kay, S.M.; Mpodozis, C. Central Andean ore deposits linked to evolving shallow subduction systems and thickening crust. Geol. Soc. Am. 2002, 11, 4-11. [CrossRef]

140. Frost, C.D.; Frost, B.R. On ferroan (A-type) granitoids: Their compositional variability and modes of origin. J. Petrol. 2010, 52, 39-53. [CrossRef]

141. Tomurtogoo, O.; Windley, B.F.; Kroner, A.; Badarch, G.; Liu, D.Y. Zircon age and occurrence of the Adaatsag ophiolite and Muron shear zone, central Mongolia: Constraints on the evolution of the Mongol-Okhotsk ocean, suture and orogen. J. Geol. Soc. 2005, 162, 125-134. [CrossRef]

142. Larson, R.L.; Olson, P. Mantle plumes control magnetic reversal frequency. Earth Planet. Sci. Lett. 1991, 107, 437-447. [CrossRef]

143. Du, J.Y.; Song, W.M.; Yang, J.L.; Tao, N.; Pang, X.J.; Yang, Y. An analysis of Zircon U-Pb age, geochemistry and tectonic setting of Dongfu pluton in Tuquan, middle Da Hinggan Mountains. Geol. Bull. China 2020, 39, 919-928.

144. Zhou, J.B.; Shi, A.G.; Jing, Y. Combined NE China Blocks: Tectonic Evolution and Supercontinent Reconstructions. J. Jilin Univ. 2016, 46, 1042-1055. (In Chinese with English Abstract)

145. Han, W.; Zhou, J.B. Paleo-Pacific subduction-accretion: Geochemical and geochronology constraints from the Raohe accretionary compelx, NE China. Acta Petrol. Sin. 2020, 36, 703-725.

146. Engebretson, D.C.; Cox, A.; Gordon, R.G. Relative Motions between Oceanic and Continental Plates in the Pacific Basin. In Geological Society of America Bulletin; Engebretson, D.C., Cox, A., Gordon, R.G., Eds.; Geological Society of America Special Papers; Geological Society of America: Boulder, CO, USA, 1985; Volume 206, pp. 1-60.

147. Chang, Z.G.; Dong, G.C.; Mo, X.X.; Dong, P.S.; Li, H.W. Early Cretaceous bimodal volcanic rocks in the Yinshan belt, North China Craton: Age, petrogenesis, and geological significance. Int. J. Earth Sci. 2020, 109, 2189-2207. [CrossRef]

148. Maruyama, S.; Send, T. Orogeny and relative plate motions: Example of the Japanese Islands. Tectonophysics 1986, 127, 305-329. [CrossRef]

149. Zhu, G.; Liu, C.; Gu, C.C.; Zhang, S.; Li, Y.j.; Su, N.; Xiao, S.Y. Oceanic plate subduction history in the western Pacific Ocean: Constraint from late Mesozoic evolution of the Tan-Lu Fault Zone. Sci. China Earth Sci. 2018, 48, 386-405. (In Chinese with English Abstract) [CrossRef]

150. Jahn, B.M.; Wu, F.Y.; Lo, C.H.; Tsai, C.H. Crustmantle interaction induced by deep subduction of the continental crust: Geochemical and $\mathrm{Sr}-\mathrm{Nd}$ isotopic evidence from post-collisional mafic-ultramafic intrusions of the northern Dabie complex, central China. Chem. Geol. 1999, 157, 119-146. [CrossRef]

151. Luchitskaya, M.V.; Morozov, O.L.; Palandzhyan, S.A. Plagiogranite magmatism in the Mesozoic island-arc structure of the Pekulney Ridge, Chukotka Peninsula, NE Russia. Lithos 2004, 79, 251-269. [CrossRef]

152. Pearce, J.A.; Harris, N.B.W.; Tindle, A.G. Trace element discrimination diagrams for the tectonic interpretation of granitic rocks. J. Petrol. 1984, 25, 956-983. [CrossRef] 
153. Liu, Y.J.; Liu, B.Q.; Feng, Z.Q.; Wen, Q.B.; Li, W.M.; Zhang, T.A.; Li, X.Y.; Du, B.Y. Petrogeochemistry and Its Tectonic Implication of Laodaokou Diorite in the Mid-North Part of Great Xing'an Range. J. Jilin Univ. 2016, 46, 482-498.

154. Shi, L.; Zheng, C.Q.; Yao, W.G.; Li, J.; Xu, J.L.; Gao, Y.; Cui, F.H. Geochronology, petro-geochemistry and tectonic setting of the Hamagou forest farm A-type granites in the Wuchagou region, central Great Xinggan range. Acta Geol. Sin. 2013, 87, $1264-1276$. (In Chinese with English Abstract)

155. Yang, H.B.; Wang, W.D.; Yan, Y.S.; Wei, X.Y.; Geng, C.B. Origin of basalts of the Tamulangou Formation and mantle enrichment in Xinlin area, Northern Greater Hinggan Mountains. Geol. Rev. 2016, 62, 1471-1486. (In Chinese with English Abstract) 